\title{
Measuring the nutritional cost of insect infestation of stored maize and cowpea
}

\author{
Tanya E. Stathers ${ }^{1}$ (D) - Sarah E. J. Arnold ${ }^{1} \cdot$ Corinne J. Rumney ${ }^{1} \cdot$ Clare Hopson $^{1}$
}

Received: 17 May 2019 / Accepted: 4 December 2019 / Published online: 8 February 2020

(C) The Author(s) 2020

\begin{abstract}
Our understanding and prevention of postharvest losses are critical if we are to feed a growing global population. Insect infestation-related losses of stored commodities are typically considered only in terms of quantitative, physical weight loss. Insect infestation affects the nutritional value and some nutritional components are impacted more severely than others. We infested maize and cowpea grain with commonly occurring stored product insect pests, and mapped infestation levels against nutritional composition over a 4-to-6 month storage period to analyse how insect infestation relates to different macro- and micronutrient contents. Insect infestation decreased the carbohydrate content of the stored grains, causing a relative increase in the proportion of protein and fibre in the remaining grain, and moisture content also increased. Sitophilus zeamais preferentially fed in the floury endosperm of maize, resulting in more carbohydrate loss relative to protein loss. Conversely, Prostephanus truncatus consumed the germ and endosperm, disproportionately reducing the fat, protein, iron and zinc grain contents. Nutrients are distributed more homogenously within cowpea than in maize grains, but Callosobruchus maculatus infestation increased the relative protein, fat, iron and zinc to carbohydrate ratios. This indicates how the nutrient content of insect-infested stored grain depends upon the grain type, the infesting insect, and the infestation level. Insect infestation therefore has consequences for human nutrition beyond those of grain weight loss. Using data collected on the changing nutritional composition of grain over time, with and without insect infestation, we modelled the associations between infestation and nutritional quality to predict estimated nutritional losses that could be associated with consumption of insect-infested stored maize and cowpea.
\end{abstract}

Keywords Nutrition · Postharvest losses · Grain storage losses · Carbohydrate: Protein ratio · Sitophilus zeamais · Prostephanus truncatus $\cdot$ Callosobruchus maculatus

\section{Introduction}

Agricultural research predominantly focuses on increasing the productivity of food crops and livestock to meet the projected nutritional needs and changing dietary tastes of a rapidly growing and urbanising human population. Much less research attention has focused on ensuring that the quality and quantity of these harvests is maintained postharvest.

Electronic supplementary material The online version of this article (https://doi.org/10.1007/s12571-019-00997-w) contains supplementary material, which is available to authorized users.

Tanya E. Stathers

t.e.stathers@gre.ac.uk

1 Natural Resources Institute (NRI), University of Greenwich, Chatham Maritime, Kent ME4 4TB, UK
However, growing awareness of the socio-ecological costs of food production, food loss and the political ramifications of the food price hike associated food crises of the 1970s and $2007 / 08$ have seen postharvest loss reduction reappearing as a development priority (World Bank et al. 2011; Gustavsson et al. 2011; Foresight Review 2011; FAO 2013; Hodges and Stathers 2013; Mvumi and Stathers 2014; Godfray and Garnett 2014; Affognon et al. 2015; Sheahan and Barrett 2017). In sub-Saharan Africa (SSA) where over 307 million people are already affected by severe food insecurity (FAO et al., 2017), the prevalence of undernourishment has recently started increasing again, reaching $22.8 \%$ in 2018 (FAO et al. 2019). The region is considered highly vulnerable to the impact of climate change (Niang et al. 2014) since its population is projected to double to 2.4 billion people by 2050 (UNDESA 2017), and is dependent on rain-fed agriculture. Given the compounding and increasing vulnerabilities and challenges facing SSA countries, reducing the losses in food crops, which 
occur both pre- and post-harvest, is imperative (Oerke 2006; Gregory et al. 2009; World Bank et al. 2011; Gustavsson et al. 2011; Savary et al. 2012; Savary et al. 2017; Stathers and Mvumi in press).

Following maturation of a crop in the field, harvests enter a series of stages prior to consumption, termed postharvest activity stages. These stages vary by crop and agricultural setting, but typically include: field drying, harvesting, transport, further drying, shelling or threshing, winnowing, storage, further processing (i.e. milling), transport to market, market storage and retailing. Postharvest losses occur when the quantity or quality (i.e. nutritional or financial value, grain viability or brewing ability, etc.) of the crop decreases during these stages.

Good postharvest management to reduce postharvest losses that affect both the quantity and quality of food, can positively influence the main components of food and nutrition security: availability, stability, access and utility-safety-quality (see Stathers et al. 2013 and Sheahan and Barrett 2017 for further discussion of the postharvest aspects of food security; and Schmidhuber and Tubiello 2007 and Savary et al. 2017 for the components of food security).

A large proportion of the grain postharvest research to date has focused on quantitative physical losses, typically expressed using dry weight loss, which is the standard international measure of grain loss (De Lima 1979; Boxall 1986). Additionally, most of the work which has measured (as opposed to estimated) quantitative postharvest losses in cereal or legume grain crops has focused on losses which occur while the crop is stored at the farmers' homestead or in warehouses or traders' stores (Hodges 2013; Hodges et al. 2014; Affognon et al. 2015; Stathers et al. 2018). As significant quantities of grain crops are lost during storage due to attack by insects, rodents and/or fungi, or contaminated by toxins or chemical residues, considerable research and development efforts have concentrated on introducing technologies and skills to help farmers reduce crop storage losses. However, this focus on the physical quantitative loss underestimates the overall value and multi-dimensional nature of postharvest losses, as the quality as well as the quantity of the crop can diminish postharvest. Although postharvest quality loss due to fungal infestations and the associated mycotoxin problems (Wild and Gong 2010; Ayalew et al. 2016) is a major global issue, there has been limited work on measuring the value of insect-mediated postharvest losses in quality (Hodges 2013; Affognon et al. 2015). Such quality losses can affect the market price of the commodity and have an impact on household nutrition and income.

Science-based contextualised estimates of the quantitative postharvest losses occurring at each postharvest stage for the main cereal crops in each province of 38 SSA countries are provided by the African Postharvest Losses Information Systems (APHLIS www.aphlis.net) (Rembold et al. 2011; Hodges et al. 2014), to assist in better targeting of loss reduction investments. APHLIS is currently being expanded to include quantitative postharvest losses data on key legume and root and tuber crops, and the financial and nutritional values of postharvest losses (Stathers et al. 2018).

The 'Missing Food' study estimated that $13.5 \%$ of the cereal grain produced across SSA is lost postharvest, equivalent to US\$4 billion per year or the annual caloric requirement of 48 million people (World Bank et al. 2011). These financial and nutritional calculations assume that these losses vary linearly with weight loss, and convert the weight loss into kilofor-kilo market value and/or the equivalence in number of people's annual nutritional requirements. However, the loss in quality of the remaining product causes additional nutritional and financial losses.

A set of trials were developed to improve our understanding of the nutritional consequences of postharvest losses, and specifically to quantify the effect of damage by storage insect pests on the nutrient value of stored maize and cowpea (two key SSA staple food grains). In these laboratory trials, we analysed the changes in the nutrient composition of smallholder farmer grown varieties of maize and cowpea grain (one white hybrid maize variety, one proVitamin A biofortified orange maize variety, and one cowpea variety) after different storage durations in the absence or presence of different combinations and initial infestation levels of the main storage insect pests. The associations we found between insect infestation and nutritional quality were used to create a prototype of a predictive tool to support more refined estimates of the nutritional losses associated with insect-infested stored maize and cowpea.

\section{Overview of research on the impact of insect infestation on nutritional value of stored grain}

Grain that is damaged or deteriorates postharvest will often be sold at a lower value at market, whether formal or informal grain quality standards are used. Quality losses can be more difficult to measure and express than quantity losses as the threshold for acceptance/rejection of the grain can depend strongly on the socioeconomic context in which the grain is being sold or consumed (Compton et al. 1998; Hodges and Stathers 2013; Hoffman and Gatobu 2014; Jones et al. 2018). This has led most economic loss studies to focus on the visible effect of postharvest insect damage (for further information see: Compton et al. 1998; Golob et al. 1999; Langyintuo et al. 2003, 2004; Jones et al. 2014, 2016, 2018; Kadjo et al. 2016; Mishili et al. 2007, 2011), and ignore invisible aspects such as mycotoxins or chemical residues (see Hoffman and Gatobu 2014, Wu et al., 2011). While it differs by location, crop and timing; when $5-10 \%$ of grains are damaged by insects, moderate discounts typically occur, but when damage increases to $20-30 \%$ of grains they may become unmarketable (Jones et al. 2018). Other factors such as discoloration, shrivelling, smell, evidence 
of chemical residues (Riwa et al. 2005), broken grains, and presence of foreign matter are also known to affect consumers' evaluation of grain quality and are key criteria in grain quality standards (Hodges and Stathers 2012).

Substantial research on the chemical changes in insectinfested and uninfested stored cereal and legume grains took place between 1950 and the mid 1980's. These findings together with those from more recent work are summarised in Table 1.

Where whole grains are lost postharvest, such as when cobs/ pods or scattered grains are left in the field after harvest, a $2 \%$ loss (e.g. $2 \mathrm{~kg}$ of whole grains out of $100 \mathrm{~kg}$ ) equates to the uniform loss of $2 \%$ of all the nutrients in that volume of grain. Conversely, when insects attack grains, only the parts of the grain ingested or excavated by the insect are lost. Many insects, however, feed selectively on only part of the grain (e.g. the germ or endosperm). In many crops, nutrients are not evenly distributed throughout the grain (Rees and Hammond 2002), therefore a 2\% loss due to insect feeding may result in a disproportionate loss of particular nutrients depending on which part of the grain is consumed by the insects.

Table 1 Overview of research findings on the effect of insect infestation on nutritional aspects of stored grains

$\begin{array}{ll}\text { Insect-infested stored grain } & \text { Un-infested stored grain }\end{array}$

Protein, nitrogen and amino acids

$\boldsymbol{\Delta}$ total nitrogen content in wheat, finger millet, maize, grams, bean and cowpea (Pingale et al. 1954; Irabagon 1959; Rajan et al. 1975; Murthy and Kokilavani 1980; Francis and Adams 1980)

$\boldsymbol{\nabla}$ protein quality (Protein Efficiency Ratio (PER)) of maize and cowpea due to severe infestation (Rajan et al. 1975, 1975a)

A soluble protein, crude protein and total protein content (Francis and Adams 1980; Tongjura et al. 2010)

Fats and lipids

A fat content in maize with heavy weevil infestation (Irabagon 1959; Tongjura et al. 2010)

$\Delta$ free fatty acids in maize, sorghum and legumes (Pandey and Pandey 1977; Venkat Rao et al. 1958, 1960).

- protein (Baldi et al. 1977 cited in Zhou et al. 2002; Dejene et al. 2006)

$\nabla$ protein solubility and in vitro digestibility

$\Delta$ amino-N

Carbohydrate, fibre and calories

- depending on insects' feeding habits and type of grain:

$\boldsymbol{\nabla}$ caloric value by endosperm feeders (e.g. Sitophilus spp)

$\boldsymbol{\nabla}$ vitamins by germ feeders (e.g. Ephestia cautella)

$\boldsymbol{\nabla}$ outer bran and starchy endosperm when larvae are external grain feeders

$\boldsymbol{\Delta}$ relative level of dietary fibre, when insects hollow out kernels and leave the pericarp

- between grain types due to differential nutrient distribution; in legumes,

larval feeding affects carbohydrates, proteins and vitamins

Vitamins and minerals

$\boldsymbol{\nabla}$ vitamins by germ feeding insects (e.g. Ephestia cautella)

- fats, protected from oxidation

At high temperatures or $m c$ :

$\boldsymbol{\nabla}$ total lipids

$\boldsymbol{\Delta}$ free fatty acids leading eventually to rancidity

- starch

$\boldsymbol{\nabla}$ soluble carbohydrates due to respiration (Dejene et al. 2006)

$\boldsymbol{\Delta}$ reducing sugars over time

$\boldsymbol{\nabla}$ non-reducing sugars over time

At high temperatures or $\mathrm{mc}$ :

$\boldsymbol{\nabla}$ starch content, carbohydrate fermentation and sour odours (Zeleny 1968)

$\boldsymbol{\nabla}$ carotenes, tocopherols, vitamin E, thiamine (vitamin B1), riboflavin (vitamin B2) depending on storage conditions (Kodicek et al. 1959; Weber, 1987; Burt et al., 2010; Mugode et al. 2014; De Moura et al. 2015; Bechoff and Dhuique-Mayer 2017; Taleon et al. 2017) - minerals

Other aspects

A contamination due to insect fragments, excreta, dust and damaged grains

$\boldsymbol{\nabla}$ baking qualities, taste, odour and flour appearance due to metabolic by-products e.g. quinones secreted by tenebrionid pests (Ladisch et al. 1968; Smith et al. 1971)

$\boldsymbol{\Delta}$ entry by pathogens and toxin development, due to seed coat damage, insect carriage of fungal spores and mycotoxin link (Agrawal et al. 1957; Widstrom 1979). Although, on wheat, it took several thousand insects per $\mathrm{kg}$ to cause an obvious increase in fungal populations (Fourar-Belaifa et al. 2011)

$\boldsymbol{\nabla}$ grain palatability leading to reduced weight gain in rats (Rajan et al. 1975, 1975a; Irabagon 1959; Jood and Kapoor 1992)

A weight of chickens fed S. zeamais infested diet (Lopez-Verge et al. 2013)

Key: $\boldsymbol{\Delta}$ = increase in; $\boldsymbol{\nabla}=$ decrease in; $\bullet$ = varies; $-=$ no change in. (Data source: as specified and/or FAO 1983). 
The protein, carbohydrate, fibre and crude fat contents of the pericarp, endosperm and germ fractions of maize grains were analysed by Nuss and Tanumihardjo (2010); Fig. 1), with similar findings reported by Naves et al. 2011. Comparable analysis of the embryo, seed coat and cotyledons of cowpea grains was reported by Singh et al. (1968); Fig. 1). These studies highlight the differential distribution of nutrients within the grains.

Some storage pests (insects and rodents), are known to selectively feed on particular parts of the maize grain, for example the germ, which is relatively rich in protein, fat and some vitamins (Fig. 2). While the cowpea grain is somewhat more homogeneous, there are still spatial trends in where and how insect pests feed. Differential damage patterns by the storage insect pests, Prostephanus truncatus (the larger grain borer) and Sitophilus species (the weevils) have been reported, with Sitophilus tending to avoid the germ, and performing poorly if the larva has no access to the endosperm (Sharifi 1972; Sharifi and Mills 1971). Conversely, P. truncatus is reported to feed and tunnel either randomly (Subramanyam et al. 1987) on the germ and the endosperm (Ramirez and Silver 1983) or with an age-based preference changing from the endosperm in early instars to the germ in later instars in two studies (Demianyk and Sinha 1988; Vowotor et al. 1998) where eggs were artificially introduced into the endosperm of grains. However, some of these studies took place in wheat, rather than maize, the more important crop in SSA. Insect damage to different parts of the grain will result in different nutritional losses and therefore understanding how the insects use the grain has important implications for human health.

\section{Methods}

\subsection{Setting up grain storage bioassay jars}

Glass jars (850 ml; Pattesons Glass Ltd., Grimsby, UK) were washed and then heat-sterilised, and once cool had fluon (Blades Biological Ltd., Edenbridge, UK) applied around the rim to prevent insect escapes. Sixty-nine jars were assigned to the white hybrid maize trial, 15 to the pro-Vitamin A (pVA) biofortified orange maize trial, and 36 to the cowpea trial. Jars were numbered, provisioned with grain and then randomly assigned to one of the infestation treatments.

\subsection{Source of grain and insects}

Freshly harvested, sun-dried, shelled and hand-sorted maize and cowpea grains were sourced from smallholder farmers in Guruve and Mbire districts of Zimbabwe respectively, by the University of Zimbabwe postharvest team and then shipped in woven polypropylene sacks to the UK. The white hybrid maize variety used was SC719, the pVA biofortified orange maize variety used was ZS242, and the red cowpea variety used was $\mathrm{CBC} 2$. On arrival at the NRI laboratories in the UK, the maize and cowpeas were re-bagged into $5 \mathrm{~kg}$ lots and sealed inside two high density transparent polyethene bags and frozen to kill any live insects; the cowpeas were frozen for $72 \mathrm{~h}$ and the maize for 1 week. Each grain type was sieved and hand-sorted to remove any foreign matter (e.g. chaff, small stones, insects, pieces of cob or seed pods, etc.) and damaged grains, to enable the trial to be set-up using grain without holes or signs of insect, fungal or rodent damage. The grain was then placed in clean metal trays (of $\sim 10 \mathrm{~kg}$ capacity) in a controlled temperature and humidity room for one week (26 $\pm 1{ }^{\circ} \mathrm{C}, 60 \%$ r.h.) to allow it to equilibrate prior to setting up the experiments. The grains in the trays were turned and mixed twice per day during this equilibration period. The trays of each grain type were then mixed together to homogenise each of the grain types prior to measuring out $300 \mathrm{~g}$ of the grain into each jar for the experiment.

Sitophilus zeamais Motschulsky (Coleoptera: Curculionidae) was sourced from Zimbabwe from infested maize grain and shipped to the UK under license. The species identity was checked by examination of the males' aedeagus (Dobie et al. 1991). Prostephanus truncatus (Horn) (Coleoptera: Bostrichidae) was also sourced from Zimbabwe
Fig. 1 Proportional distribution of macronutrients within maize and cowpea grains and diagrammatic structure of longitudinal section of a maize and a cowpea grain (Data source: Singh et al. 1968; Nuss and Tanumihardjo 2010)

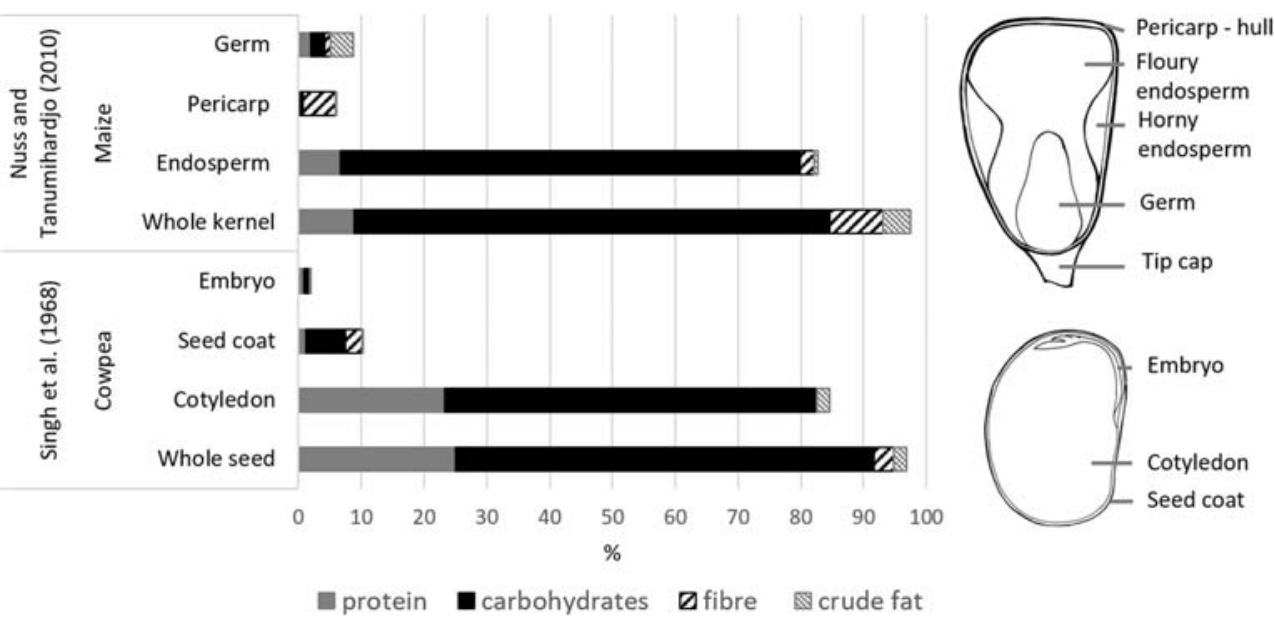


Fig. 2 Maize grains heavily damaged by a) Sitophilus zeamais, b) Prostephanus truncatus, c) rodents
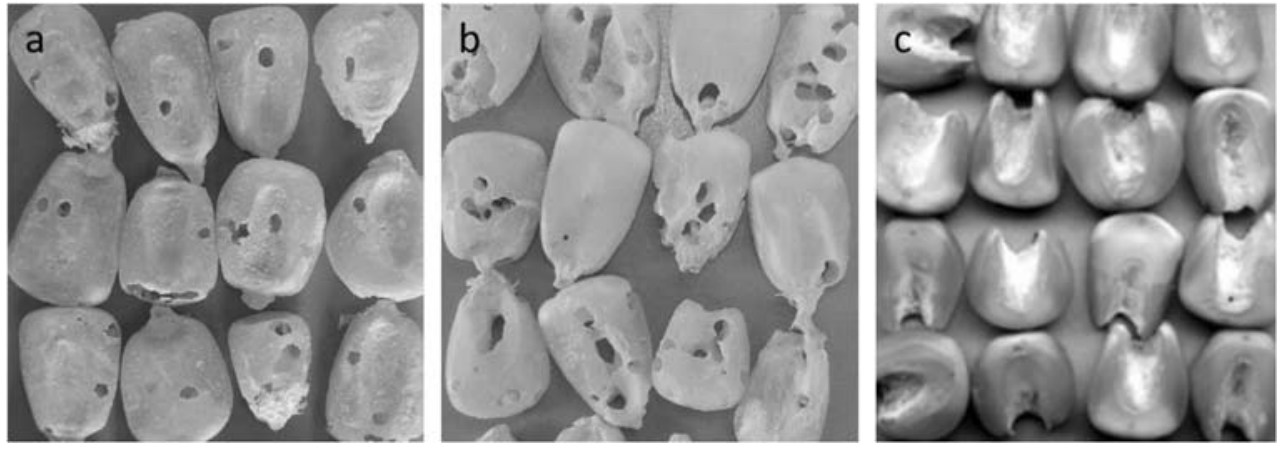

from infested maize grain and species identity confirmed by observation under a microscope. Both species were maintained on white hybrid maize grain from Zimbabwe (the same as that used in the experiments). Callosobruchus maculatus (Fabricius) (Coleoptera: Bruchidae) was sourced from an existing culture at the Natural Resources Institute, UK, originally obtained from infested cowpea in Ghana.

\subsection{Insect infestation of grain}

Five treatments were implemented on the white maize grain: (a) control (no insects); (b) S. zeamais (low level; two male plus two female 7-21 day old adults); (c) S. zeamais (high level; 20 unsexed 7-21 day old adults); (d) P. truncatus (two male plus two female 7-14 day old adults); (e) both insect pests (two male and two female $S$. zeamais and two male and two female $P$. truncatus 7-14 day old adults). For the pVA biofortified orange maize, two treatments were used: (a) control (no insects); (b) both insect pests (two male and two female $S$. zeamais and two male and two female $P$. truncatus 7-14 day old adults). For cowpea, three treatments were used: (a) control (no insects); (b) C. maculatus (low level; two male plus two female 0-3 day old adults); (c) C. maculatus (high level; 20 unsexed 0-3 day old adults).

Even the low infestation levels were anticipated to reach high population densities within 2-3 months, however, attempting experiments with a single female as the founder was considered to carry an unacceptable risk of early mortality or atypical fecundity so two females was considered the minimum required to ensure infestation occurred. Three jars were assigned to each combination of infestation type $\mathrm{x}$ grain type $\mathrm{x}$ duration of infestation (Table 2).

After addition of insects (if any), jars were sealed with a $70 \mathrm{~mm}$ filter paper (Schleicher \& Schuell, Dassel, Germany, or Whatman No. 1 cut to fit the $70 \mathrm{~mm}$ jar opening) held in place by paraffin wax.

As the 0-month replicates for the infestation treatments were all identical, only three jars were used for the 0 -month time point for each grain type.

Destructive sample analysis of the cowpea grains was done at 1, 2, 3 and 4 months' storage, while the white maize was destructively sampled at 1, 2, 4, 6 and 8 months' storage, and the pVA biofortified orange maize at 1 and 4 months' storage.

\subsection{Storage conditions and sampling}

All the jars of grain were stored in a controlled temperature and humidity chamber, set to $26^{\circ} \mathrm{C}$ and $60 \%$ relative humidity with a 12:12 h light: dark cycle. After the different assigned storage durations (Table 2), the relevant subset of jars (three replicates for each grain type $\mathrm{x}$ insect combination $\mathrm{x}$ storage duration) were removed from the chamber, opened and destructively sampled using the damage assessment procedure described below. The cowpea storage trial ran from September 2017 to January 2018, and the maize trials from September 2017 to May 2018.

\subsection{Damage assessment of sample}

The contents of each jar were weighed and sieved (nested metal sieves with apertures of $4.75 \mathrm{~mm}$ and $1 \mathrm{~mm}$ were used for white maize, and $2 \mathrm{~mm}$ and $1 \mathrm{~mm}$ for cowpea and pVA biofortified orange maize). The sieving process used involved one minute of manual shaking, one minute of rest and a further minute of shaking to separate the trash and insects from the grains. The weight of the trash and the insects were recorded along with the number and species of dead and live insects, except for the later storage duration cowpea jars as they contained several thousand of the flight-form insects.

The sieved grain was then poured through a riffle-divider to produce a sub-sample of $\sim 90 \mathrm{~g}$ for damage assessment. Each grain in the sample was inspected and categorised as undamaged, insect damaged, broken (mechanical damage or damage not due to the storage insect pests), or insect damaged and broken. The total numbers and mass of the grains in each category were recorded. The percentage insect damaged grain was calculated according to the following equation:

$\%$ insect damaged grain $=\frac{N d}{(N d+N u)} \times 100$ 
Table 2 Experimental design

\begin{tabular}{|c|c|c|c|c|c|c|c|c|c|c|}
\hline \multirow[t]{2}{*}{ Grain type } & \multirow[t]{2}{*}{ Infestation } & \multirow{2}{*}{$\begin{array}{l}\text { Treatment } \\
\text { code }\end{array}$} & \multirow{2}{*}{$\begin{array}{l}\text { No. of insects added } \\
\text { to } 300 \mathrm{~g} \text { of grain }\end{array}$} & \multicolumn{7}{|c|}{ Storage duration (months) } \\
\hline & & & & 0 & 1 & 2 & 3 & 4 & 6 & 8 \\
\hline \multirow[t]{5}{*}{ White maize SC719 (69 samples) } & S. zeamais (high) & High Sz & 20 & & $\mathrm{X}$ & $\mathrm{X}$ & & $\mathrm{X}$ & $X$ & \\
\hline & S. zeamais (low) & Low Sz & 4 & & $\mathrm{X}$ & $\mathrm{X}$ & & $\mathrm{X}$ & $\mathrm{X}$ & \\
\hline & P. truncatus & Low Pt & 4 & & $\mathrm{X}$ & $\mathrm{X}$ & & $X$ & $\mathrm{X}$ & \\
\hline & S. zeamais + P. truncatus & Low SzPt & $4 \mathrm{Sz}+4 \mathrm{Pt}$ & & $\mathrm{X}$ & $\mathrm{X}$ & & $\mathrm{X}$ & $X^{\mathrm{a}}$ & \\
\hline & Non-infested control & Control & 0 & $\mathrm{X}$ & $\mathrm{X}$ & $\mathrm{X}$ & & $\mathrm{X}$ & $\mathrm{X}$ & $\mathrm{X}$ \\
\hline \multirow[t]{2}{*}{ Orange maize ZS242 (15 samples) } & S. zeamais + P. truncatus & Low SzPt & $4 \mathrm{Sz}+4 \mathrm{Pt}$ & & $\mathrm{X}$ & & & $\mathrm{X}$ & & \\
\hline & Non-infested control & Control & 0 & $\mathrm{X}$ & $X$ & & & $\mathrm{X}$ & & \\
\hline \multirow[t]{3}{*}{ Cowpea CBC2 (36 samples) } & C. maculatus (high) & High & 20 & & $\mathrm{X}$ & $\mathrm{X}$ & $\mathrm{X}$ & & & \\
\hline & C. maculatus (low) & Low & 4 & & $\mathrm{X}$ & $\mathrm{X}$ & $\mathrm{X}$ & $\mathrm{X}$ & & \\
\hline & Non-infested control & Control & 0 & $X$ & $\mathrm{X}$ & $X$ & $\mathrm{X}$ & $\mathrm{X}$ & & \\
\hline
\end{tabular}

Key: X indicates 3 replicates of that treatment. $X^{\mathrm{a}}$ indicates 6 replicates of the treatment were included; the insect population in the LowSzPt treatment replicates reached such high populations by 6 months that samples were taken at 6 months rather than the originally planned 8 months, in order to prevent escapes.

with $\mathrm{Nd}$ representing the number of insect damaged grains, and $\mathrm{Nu}$ representing the number of undamaged or non-insect damaged grains (Boxall 1986).

Percentage grain weight loss was calculated using the formula:

Attainable yield $(Y a)=(N u+N d) \times W u 1$

Actual yield $(Y)=(N u \times W u 1)+(N d \times W d 1)$

$\%$ weight loss $=\frac{Y a-Y}{Y a} \times 100=\frac{(N d \times W u 1)-(N d \times W d 1)}{(N d+N u) \times W u 1} \times 100$

with Wu1 = unit weight of unaffected grain, and Wd1 = unit weight of damaged grain.

Note: this formula gives the same result as the percentage weight loss (count and weigh) formula:

$\%$ weight loss $=\frac{(W u \times N d)-(W d \times N u)}{(N d+N u) \times W u} \times 100$

with $\mathrm{Wu}=$ total weight of undamaged or non-insect damaged grains in a sample, and $\mathrm{Wd}=$ total weight of insect damaged grains (Boxall 1986; Adams and Schulten 1978).

The whole sieved sample was then re-mixed, sealed inside two ziplock plastic bags and frozen at $-20{ }^{\circ} \mathrm{C}$ until nutrient content analysis.

\subsection{Nutrient analysis of samples}

Food proximate plus iron and zinc content analyses were used to determine the nutritional composition and energy value of each sample. A summary of the nutrient composition analysis methods is given in Supplemental Table S1.
A sub-sample of the 15 pVA biofortified orange maize samples were used for analysis of the carotenoid content. The maize carotenoids were extracted as previously reported (Ortiz et al. 2016; Nkhata et al. 2019). Liquid chromatography analysis was performed using authentic all-trans-carotenoid standards and comparison with spectral information from previous separations (Kean et al. 2008) to identify the carotenoid peaks. Quantification was completed using a seven-point response curve constructed with authentic carotenoid standards in the range of $0.01-8.0 \mu \mathrm{m}$.

\subsection{Data analyses}

The experiments enabled the insect damage-related attributes and nutritional content of each sample for the three focal grains and the different initial infestation levels to be compared during a storage period of up to eight months (see Table 1). Data were analysed using $\mathrm{R}$ version 3.5.1 (R Core Team 2018).

Analyses were carried out using the grain in the state in which it had been stored, i.e. fresh-weight basis (FWB) from product previously sun-dried to $<12 \%$ moisture content, rather than analysing dry-weight basis (DWB) nutrient content. Using FWB values better reflects the nutritional situation for smallholder farmers, as food is prepared directly from stored grain rather than from the zero-moisture material that is used for DWB analysis.

For each of the three grain types, a two-way analysis of variance (ANOVA) was conducted to determine if the storage duration, the initial insect infestation level, or the interaction between them had a statistically significant effect on each of the variables considered (i.e. percentage damaged grains, percentage 
grain weight loss, protein $(\mathrm{g} / 100 \mathrm{~g})$, fat $(\mathrm{g} / 100 \mathrm{~g})$, iron $(\mathrm{mg} /$ $100 \mathrm{~g})$, zinc $(\mathrm{mg} / 100 \mathrm{~g})$, available carbohydrate $(\mathrm{g} / 100 \mathrm{~g})$, fibre (g/100 g), energy (kcal/100 g), \% moisture content, \% weight of trash, total insects $/ \mathrm{kg}$ ). Variable values were plotted by treatment and storage duration. Multiple comparisons used the Least Significant Difference (LSD) LSD.test function in the R 'agricolae' package (De Mendiburu 2019), applied to the output of a one-way ANOVA using a factor that combines the storage duration and infestation levels. This uses a Holm-corrected least significant difference method to generate groups of means which do not differ significantly at $p<0.05$, identified by compact letter display codes (Steel et al. 1997).

For each grain type, the relationships between percentage insect damage and weight loss for each of the nutrients and storage duration (months) were analysed using plots of paired variables and Spearman's rank correlations, to detect correlations between insect damage variables and each of the different nutrients considered. In these analyses, the level of insect damage as opposed to the treatments (i.e. untreated control, low initial infestation, high initial infestation, etc.) was used, as within each treatment there could be a wide range in the number of insects and the damage levels which had resulted.

An interactive storage insect damage-related nutrient loss prediction tool was developed. This tool requires the user to input (a) the initial mass of grain and (b) the percentage of insect damaged grains at the sampling time, it then calculates the predicted nutritional content of the remaining stored grain using the nutrient: insect damage correlation data.

\section{Results}

\subsection{Change in nutrient content of uninfested control commodities during storage}

The proportional content of the different nutrients did not change significantly in the uninfested control white maize grain during the storage period (Fig. 3). The nutrient content of the white hybrid maize grain, the pVA biofortified orange maize grain and the cowpea grain at the time of the trial set-up are shown in Supplemental Tables S2 and S3. The moisture content of the white hybrid maize grain was $11.7 \%$ at set-up and decreased slightly during the trial in the uninfested control grain, but not statistically significantly so.

In the uninfested control pVA biofortified orange maize grain no change occurred in the concentration of the different macronutrients, or the moisture content during the storage period. A decrease in the mean zinc content did occur in the uninfested grain, but not in the insect infested grain (Fig. 4). The concentration of all the carotenoids reduced during the four-month storage duration in both the uninfested control grain and the insect infested grain (Fig. 5).
Similarly, in the uninfested control cowpea grain, there was no significant change in the proportional content of any of the nutrients measured or the grain moisture content over the fourmonth storage period (Fig. 6).

\subsection{Relationship between insect infestation, proportion of damaged grains and grain weight loss}

\subsubsection{White maize grain}

Insect damage increased with storage duration in all the treatments to which insects were added at trial set-up (Fig. 3). The highest mean percentage of damaged grains $(83 \%)$ occurred following six months of storage of the white maize grain initially seeded with the high number of $S$. zeamais (i.e. High $\mathrm{Sz}=$ $20 \mathrm{~S}$. zeamais adult insects added to $300 \mathrm{~g}$ of maize grain at setup). Mean damage was slightly lower (58-70\%) at six months' storage in those treatments initially infested with lower numbers of insects (i.e. Low SzPt, Low Pt, Low Sz). A two-way analysis of variance (ANOVA) run on the 69 samples of white maize grain showed that storage duration $\left(\mathrm{F}_{5,47}=122.2, \mathrm{p}<0.0001\right)$ and initial insect infestation level $\left(\mathrm{F}_{4,47}=34.3, \mathrm{p}<0.0001\right)$ interacted and had a highly significant effect on percentage of damaged grains $\left(\mathrm{F}_{12,47}=11.4, \mathrm{p}<0.0001\right)$.

At trial set-up, less than $5 \%$ of grains were insect damaged; this damage was due to prior insect infestation in the field or during crop drying or transport. However, as the grain was frozen for 1 week prior to trial set-up, there were no surviving insects inside any of the damaged grains.

Grain weight loss due to insect damage also increased with storage duration, most rapidly between four and six months' storage. Grain weight loss differed significantly between treatments $\left(\mathrm{F}_{5,47}=40.8, \mathrm{p}<0.0001\right)$, reaching extremely high levels of $28-34 \%$ at six months' storage in the High Sz, Low SzPt and Low Pt treatments, but remaining lower (12\%) in the Low Sz treatment, and less than $0.7 \%$ in the uninfested control grain (Fig. 3).

\subsubsection{Pro-vitamin A biofortified orange maize grain}

Insect damage increased with storage duration in the infested pVA biofortified orange maize grain, resulting in a mean of $69 \%$ of grains being damaged at four months' storage, equivalent to a mean grain weight loss of $28 \%$ (Fig. 4). A two-way analysis of variance of the $15 \mathrm{pVA}$ biofortified orange maize samples showed that storage duration $\left(\mathrm{F}_{2},{ }_{10}=166.3\right.$, $\mathrm{p}<0.0001)$ and insect infestation $\left(\mathrm{F}_{1,10}=293.5, \mathrm{p}<\right.$ $0.0001)$, had a significant effect on percentage insect damage, with a significant interaction $\left(\mathrm{F}_{1,10}=264.2, \mathrm{p}<0.0001\right)$; and on grain weight loss (storage duration $\left(\mathrm{F}_{2,10}=16.7, \mathrm{p}=\right.$ $0.0007)$, insect infestation $\left(\mathrm{F}_{1,10}=29.6, \mathrm{p}=0.0003\right)$, with a significant interaction $\left(\mathrm{F}_{1,10}=27.0, \mathrm{p}=0.0004\right)$ (Fig. 4). 

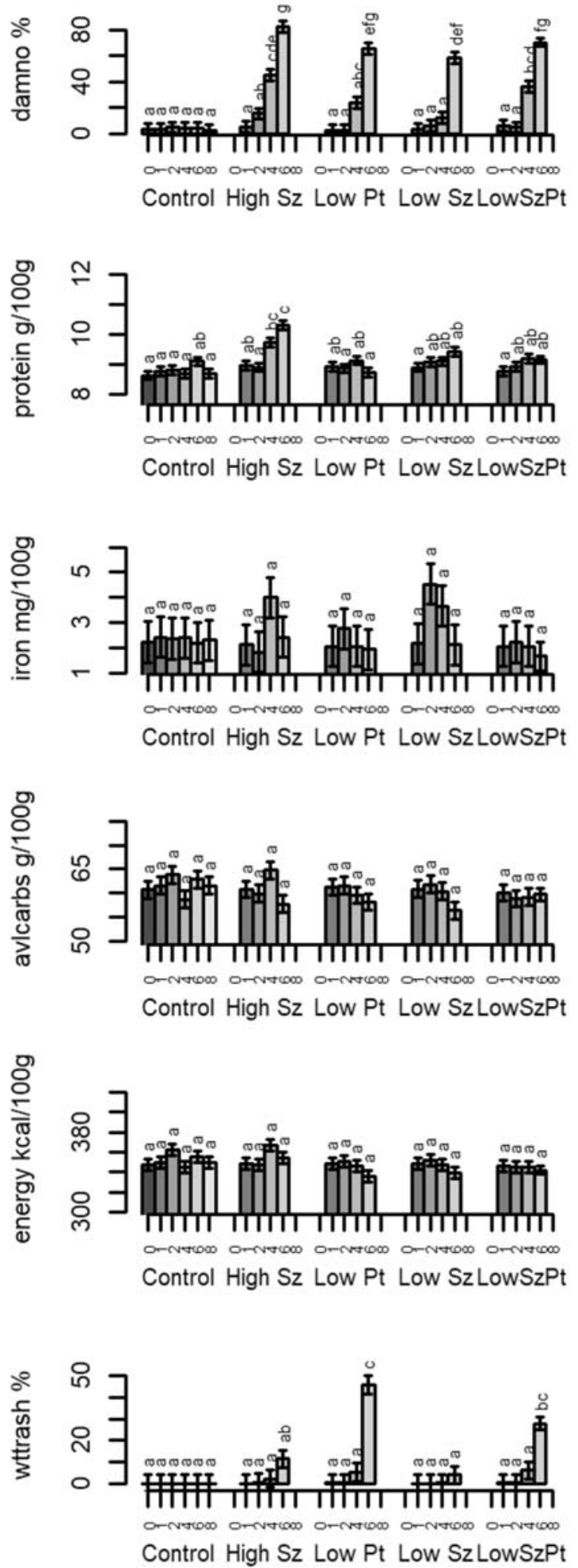

Fig. 3 Mean damage level and nutrient content of dried white maize grains infested with different numbers and species of the two main storage insect pests after different storage durations of up to 8 months $(n=3)$ (Note: $x$-axis shows treatments and storage duration - Control $(0$, 1, 2, 4, 6, 8 months), High Sz (S. zeamais), Low Pt (P. truncatus), Low Sz, LowSzPt (S. zeamais and P. truncatus) (at 1, 2, 4, 6 months); y-axis abbreviations: damno \% = percentage damaged grain (by number);
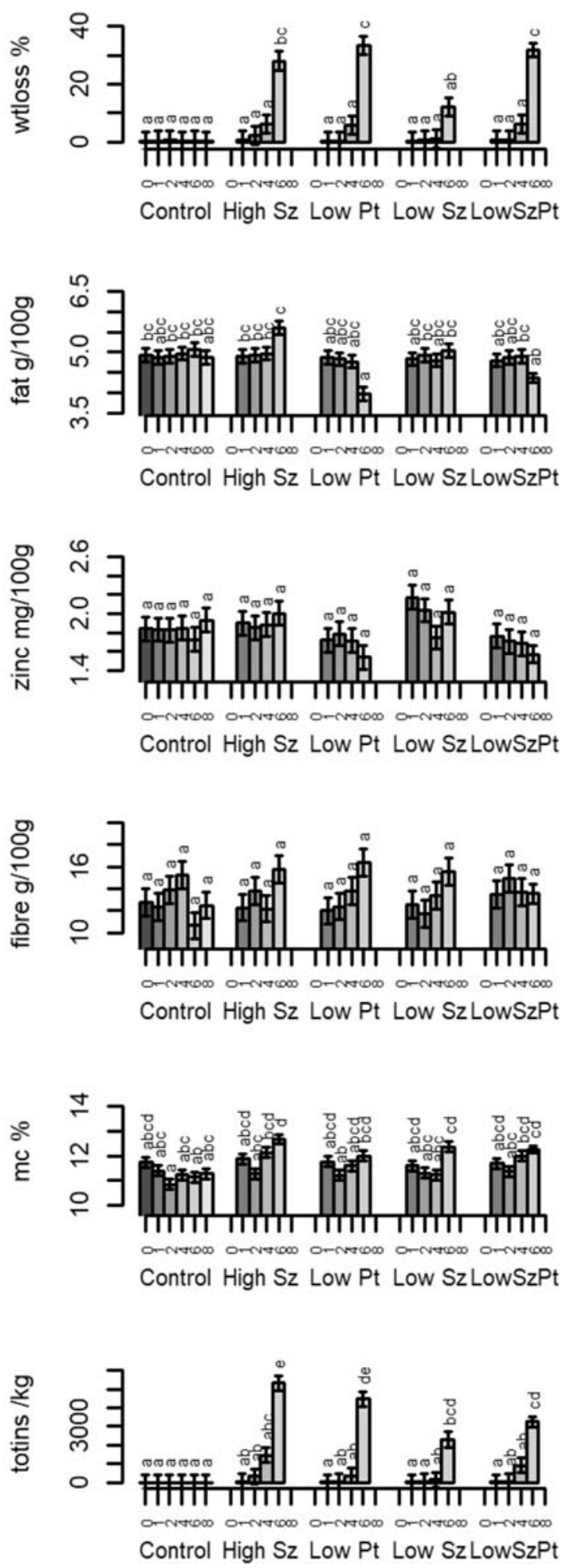

wtloss $\%=$ percentage grain weight loss; avlcarbs = available carbohydrates; $m c \%=$ percentage grain moisture content; $w$ ttrash $\%=$ percent age weight of trash; totins $/ \mathrm{kg}=$ total number of insects (live and dead for both species)/ kg. Within each chart means which are statistically significantly different from each other are denoted by different lower-case letters $(p<0.05)$ 

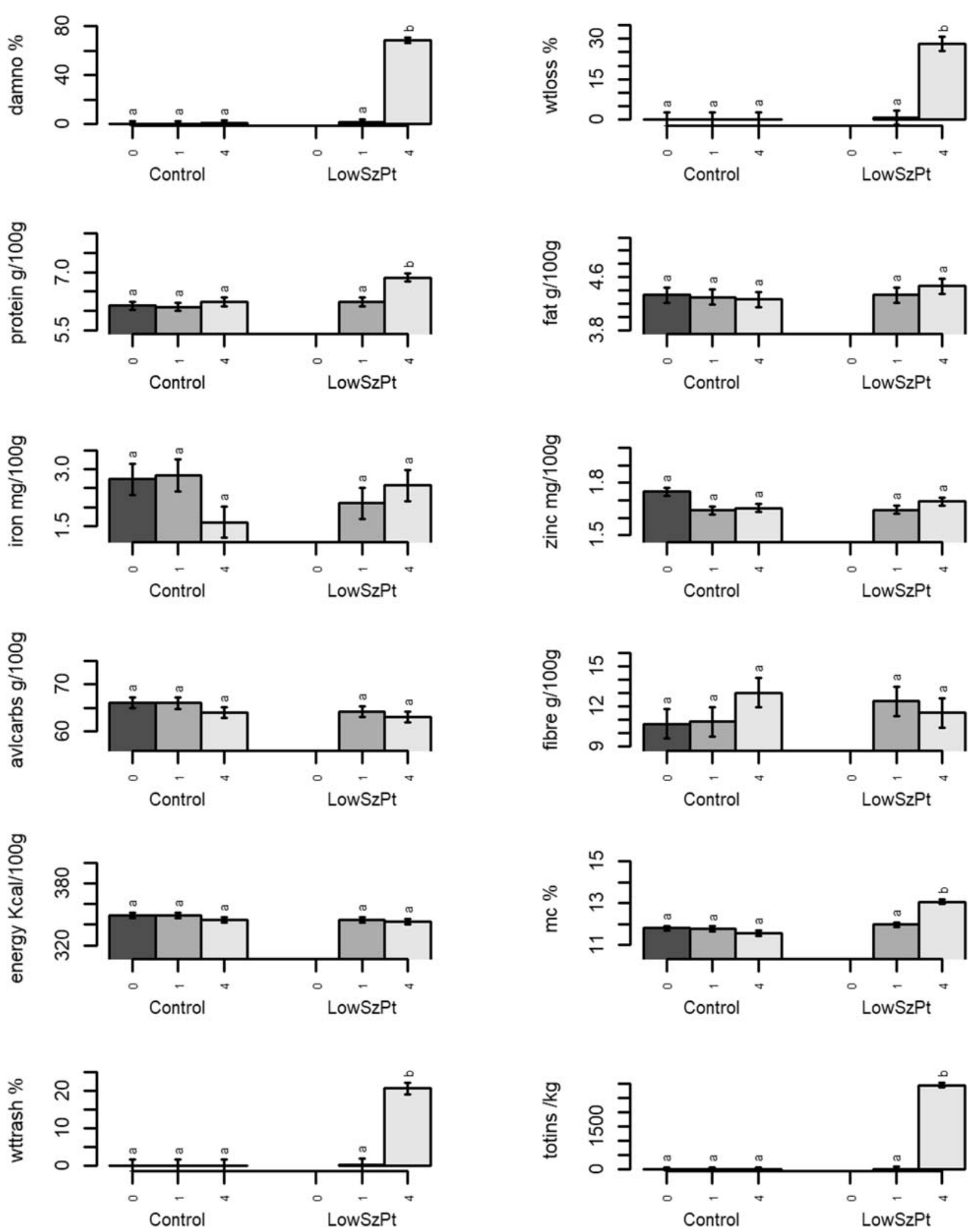

Fig. 4 Damage level and nutrient content of stored pro-Vitamin A biofortified orange maize grains with and without insect pest infestation after 0,1 and 4 months' storage (Note: $x$-axis shows treatment and storage duration - Control (0, 1, 4 months), Low SzPt (1, 4 months); y-axis

abbreviations as per fig. 3. Within each chart means which are statistically significantly different from each other are denoted by different lower-case letters $(p<0.05)$ 


\subsubsection{Cowpea grain}

Insect damage increased with storage duration in both the high and the low levels of initial insect infestation level treatments, resulting in mean of $93 \%$ and $60 \%$ damaged grains at three months storage respectively (Fig. 6). A two-way ANOVA on the 36 samples of stored cowpea showed that storage duration $\left(\mathrm{F}_{4,24}=13.1, \mathrm{p}=0.00008\right)$, initial insect infestation level $\left(\mathrm{F}_{2,24}=17.6, \mathrm{p}=0.0002\right)$ and their interaction $\left(\mathrm{F}_{5,24}=6.3, \mathrm{p}=0.0007\right)$ significantly affected the mean percentage of damaged grains. The mean percentage of damaged grains was significantly higher by three months storage in both the high and low treatments
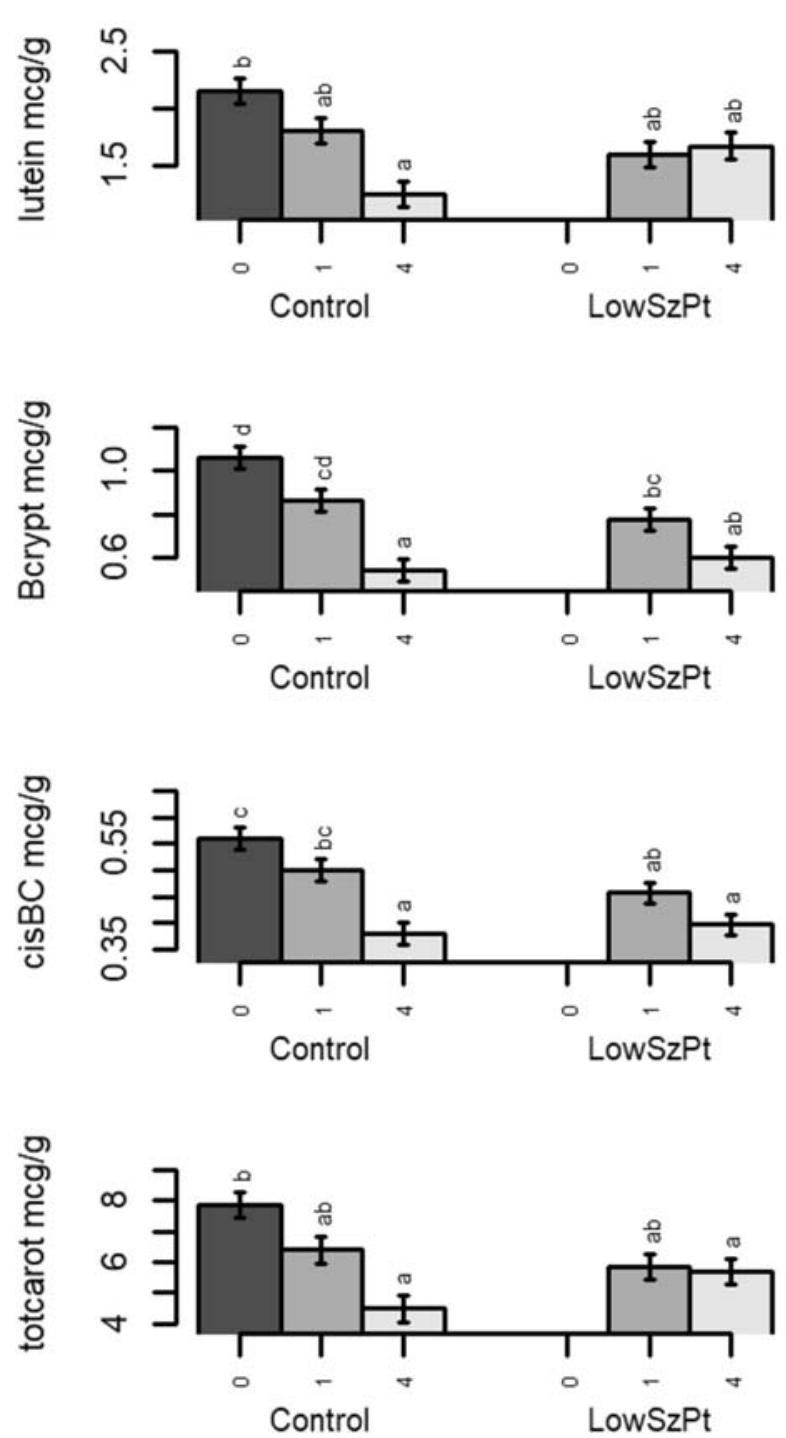

Fig. 5 Content of carotenoids in stored pro-Vitamin A biofortified orange maize grains with and without insect pest infestation after 0,1 and 4 months' storage (Note: $x$-axis shows treatment and storage durationControl (0, 1, 4 months), Low SzPt (1,4 months); y-axis abbreviations: Bcrypt $=$ Beta-cryptoxanthin; alltrans $B C=$ all trans beta-carotene; compared to the control. Although the percentage of damaged grain was higher in the high infestation treatment, than in the low infestation treatment, Least Significance Difference pairwise comparison tests did not detect significant differences (Fig. 6).

Grain weight loss of cowpea seeds also increased with storage duration in both the high and low insect infestation treatments. A two-way ANOVA showed that storage duration $\left(\mathrm{F}_{4,24}=3.1, \mathrm{p}=0.033\right)$ and initial insect infestation level $\left(\mathrm{F}_{2}\right.$, ${ }_{24}=3.8, p=0.037$ ) significantly affected the mean percentage grain weight loss. However, Least Significant Difference multiple comparison test did not detect significant differences between treatment means (Fig. 6).
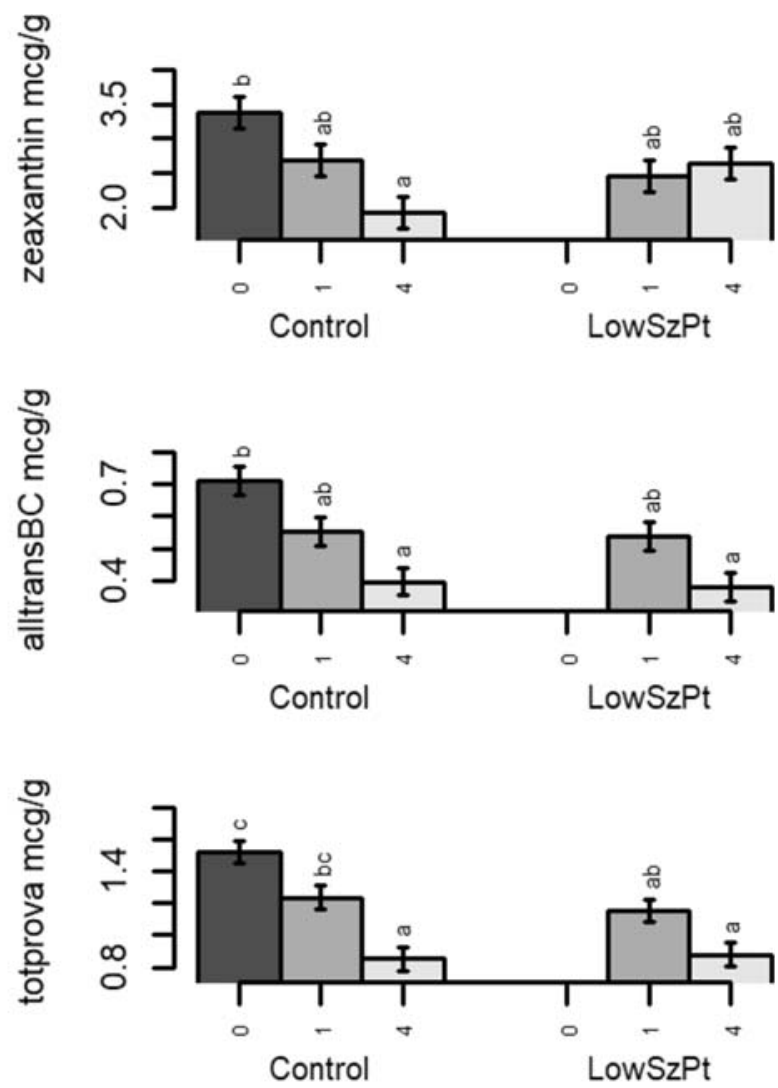

cis $B C=$ cis beta-carotene $;$ totalprova $=$ total pro-vitamin $A ;$ totalcarot $=$ total carotenoids. Within each chart means which are statistically significantly different from each other are denoted by different lower-case letters $(p<0.05)$ 

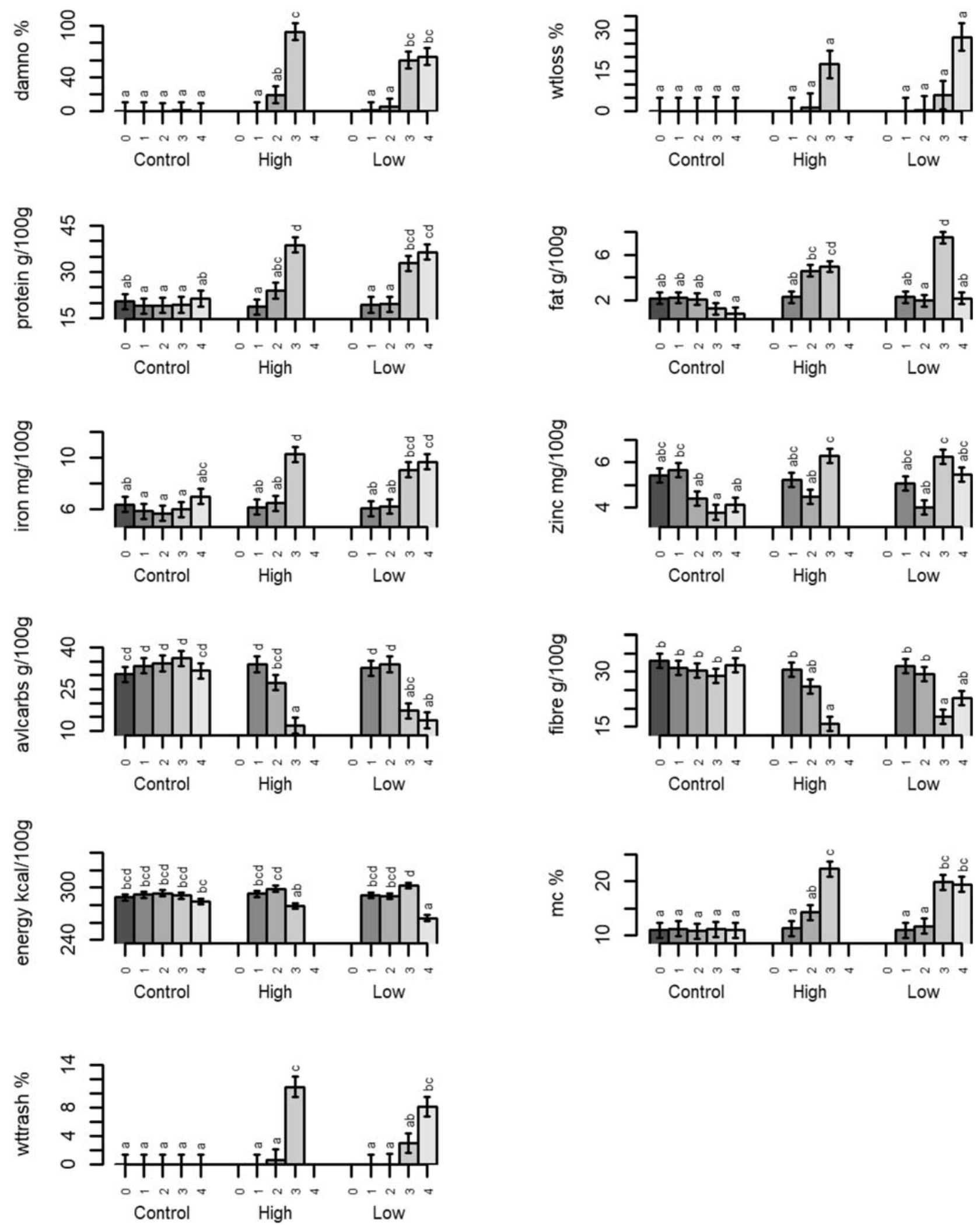

Fig. 6 Damage level and nutrient content of dried cowpea grains infested with different initial numbers of the insect pest Callosobruchus maculatus after 0, 1, 2, 3 and 4 months' storage (Note: $x$-axis shows treatments and storage duration - Control (0, 1, 2, 3, 4 months), High

C. maculatus (20 insects/ $300 \mathrm{~g}$ ) (1, 2, 3 months), Low C. maculatus (4 insects $/ 300$ g) (1, 2, 3, 4 months); $y$-axis abbreviations as per fig. 3 . Within each chart means which are statistically significantly different from each other are denoted by different lower-case letters $(p<0.05)$ 
4.3 Relationship between insect infestation and shifts in nutrient contents

The three insect damage variables considered (percentage damaged grains, percentage grain weight loss, and total insects $/ \mathrm{kg}$ ) were all significantly positively correlated with each other for all three grain types.

Moisture content of grain stored in non-airtight containers changes during the storage period in response to the relative humidity and temperature of the surrounding environment, and insect and/or fungal attack of the stored grain usually results in an increased grain moisture content. During the trial, grain moisture content ranged from $10.7 \%$ to $13.1 \%$ in the different white maize treatments $(10.7 \%$ to $11.9 \%$ in the uninfested stored maize, and $10.9 \%$ to $13.1 \%$ in the insect infested stored maize), $11.4 \%$ to $13.2 \%$ in the pVA biofortified orange maize treatments (11.4 to $12.0 \%$ in the uninfested pVA biofortified orange maize, and $11.4 \%$ to $13.2 \%$ in the insect infested pVA orange maize), and $10.5 \%$ to $24.5 \%$ in the cowpea treatments $(10.7 \%$ to $11.4 \%$ in the uninfested stored cowpea, and $10.8 \%$ to $24.5 \%$ in the insect infested cowpea).

\subsubsection{Shifts in nutrient contents in insect-infested white maize grain}

The correlations between insect infestation and nutritional composition of white maize grain are shown in Fig. 7. Increasing storage duration (months) was positively correlated with increasing percentage damaged grain (damno; $p<0.001$ ), percentage grain weight loss (wtloss; $p<0.001$ ), and total number of insects /kg (tot_ins; p < 0.001) (Fig. 3). There was also a positive correlation between increasing storage duration and the protein content of samples (protein; $\mathrm{p}<0.01$ ).

The three insect damage variables (percentage damaged grains (damno), percentage grain weight loss (wtloss), and total insects $/ \mathrm{kg}$ (tot_ins)) were all significantly positively correlated $(\mathrm{p}<0.001)$ (Fig. 7). They were all also significantly positively correlated $(\mathrm{p}<$ 0.001 ) with increasing protein content (protein), increasing moisture content $(\mathrm{mc})$ and with increasing storage duration (months). There was also a positive correlation between increasing relative fibre content (fibre) and percentage damaged grains (damno; $\mathrm{p}<0.05)$ and total insects $/ \mathrm{kg}$ (tot ins; $\mathrm{p}<0.01$ ). There was a negative correlation between relative available carbohydrate content and these three insect damage variables ((damno; $p<$ 0.01 ) (tot ins; $p<0.01$ ) (wtloss; $p<0.05)$ ), and between all three insect damage variables (damno, wtloss, tot ins) and the energy content $(\mathrm{kcal} ; \mathrm{p}<0.001)$. There was a negative correlation between the insect damage variables and relative iron content (iron; $\mathrm{p}<0.05$ ). No correlation between the insect damage variables and the relative fat or zinc content of the white maize grain occurred.

The relationships between each of the insect species (P. truncatus and S. zeamais) and nutrient composition in the white maize were also studied using a Spearman's correlation (Fig. 8). While increasing numbers of each species were correlated with increasing percentage grain weight loss, percentage damaged grains and percentage moisture content $\left(P\right.$. truncatus ( $\mathrm{Pt} \_\mathrm{pkg}$; $\mathrm{p}<0.05)$, S. zeamais $(\mathrm{Sz}$. pkg; $\mathrm{p}<0.001)$ ), only increasing numbers of $S$. zeamais were statistically significantly correlated with increased relative protein ( $\mathrm{Sz}$ pkg; $\mathrm{p}$ $<0.001)$ and fibre $(\mathrm{p}<0.05)$ concentration. Increasing numbers of both species were significantly correlated with decreasing energy kcal ( $P$. truncatus (Pt_pkg; $\mathrm{p}<$ $0.001)$, S. zeamais (Sz_pkg; $\mathrm{p}<0.01)$ ), and relative iron content $(P$. truncatus (Pt_pkg; $\mathrm{p}<0.01), S$. zeamais (Sz_pkg; $\mathrm{p}<0.05)$ ). Increasing numbers of $S$. zeamais (Sz_pkg; $p<0.01$ ) were statistically significantly associated with decreasing relative available carbohydrate content. Increasing numbers of $P$. truncatus were also significantly (Pt_pkg; p < 0.001) associated with decreasing relative fat and zinc contents, but no significant relationship occurred between $S$. zeamais numbers and these two nutrients.

The significant correlations between insect damage, mass loss and nutrient composition could be used to create a maize storage nutrient loss predictive tool to assist in estimating the quantity and concentration of different nutrients in the remaining stored product at a range of different grain damage levels, with a prototype exemplar provided as Supplemental Tool 1.

\subsubsection{Shifts in nutrient contents in insect-infested pro-vitamin A biofortified orange maize grain}

The relationships seen in the pVA biofortified orange maize samples were similar to those in the white maize, with storage duration positively correlated to percentage damaged grain (damno; $\mathrm{p}<0.01$ ), percentage grain weight loss (wtloss; $\mathrm{p}<$ 0.01 ), total insects $/ \mathrm{kg}$ (tot_ins; $\mathrm{p}<0.05$ ), relative protein (protein; $p<0.01$ ) and relative fibre content (fibre; $p<0.05$ ).

The relationships between insect damage variables and nutritional composition and moisture content and storage duration in pVA biofortified orange maize grain are visualised in the pairs plot with the result of the Spearman's rank correlations tests (Fig. 9), with the data summarised by treatment shown in Fig. 4. As with the white maize grain, in the pVA biofortified orange maize the insect damage variables were positively correlated with increasing relative protein content (protein; $p<$ $0.05)$ and increasing moisture content $(\mathrm{mc} ; \mathrm{p}<0.05)$. While there was a negative correlation between percentage weight loss 
and available carbohydrates (avlcarbs; $\mathrm{p}<0.05$ ). No statistically significant relationship was found between the three insectdamage variables and the fat, fibre, energy, iron, or zinc contents of the pVA biofortified orange maize grain. Additional analyses (not shown) found no significant correlation between $P$. truncatus numbers and fat and zinc content nor with any of the other nutrients except an increase in relative protein content (protein; $\mathrm{p}<0.05$ ) in the $\mathrm{pVA}$ biofortified orange maize, and the same was found for $S$. zeamais.

The relationship between the carotenoid composition of the pVA orange maize grain samples and the storage duration and insect damage variables was also analysed (Figs. 5 and 10).

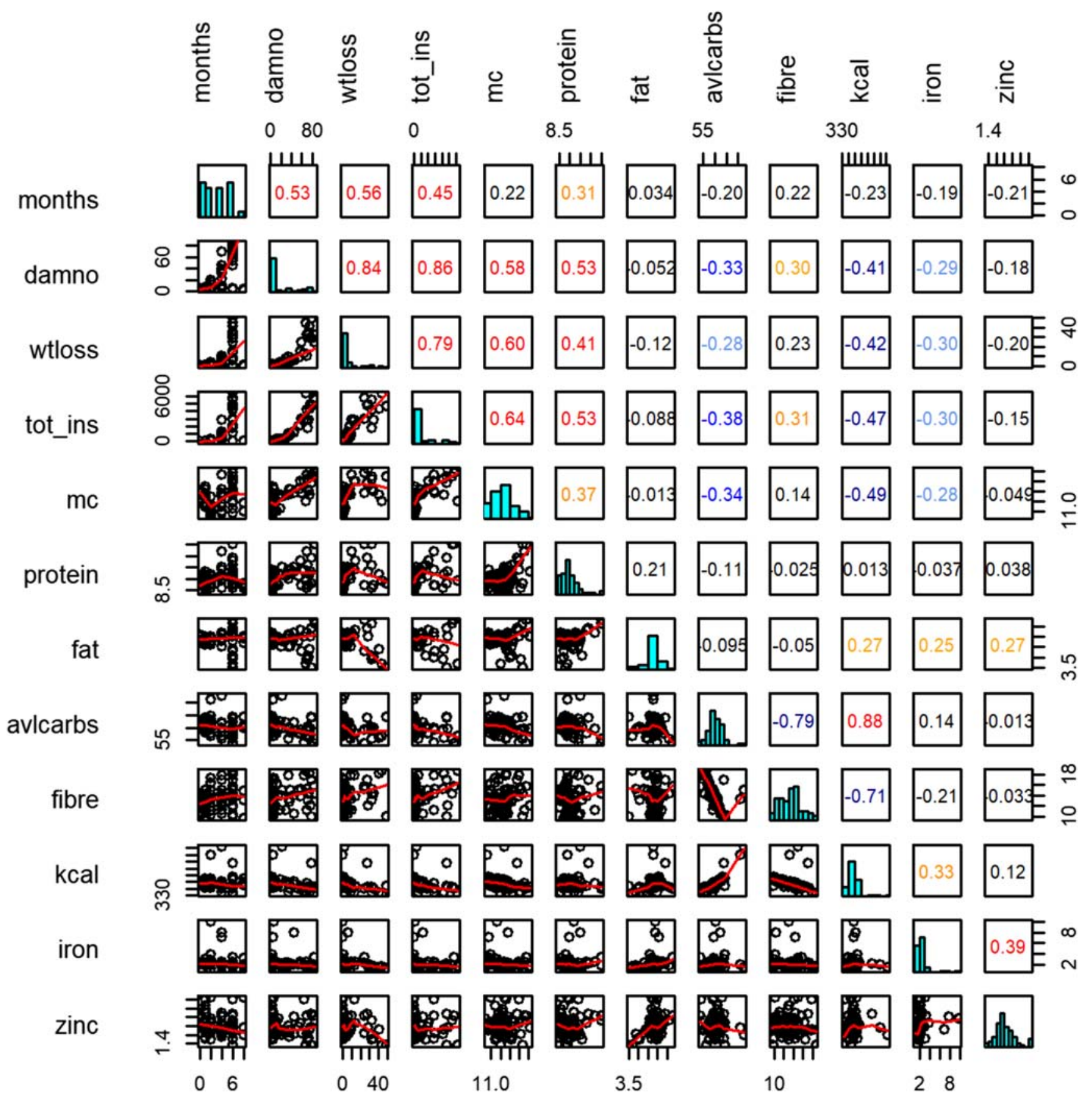

Fig. 7 Pairs plot and Spearman's rank correlations of relationships between storage insect damage factors and nutrients in white maize grain [Spearman's rank correlation critical values for $N=69$ are $p=$ $0.05 * 0.237 ; p=0.01 * * 0.309 ; p=0.001 * * * 0.390$, the significantly positive correlations are shown in shades of yellow $>$ red, and the

significantly negative correlations in shades of blue; abbreviations $=$ months $=$ storage duration; damno = percentage damaged grain (by number); wtloss = percentage grain weight loss; totins = total number of insects $/ \mathrm{kg} ; m c=$ percentage grain moisture content; avlcarb = available carbohydrates; $k c a l=$ energy $(k c a l / 100 \mathrm{~g})]$ 


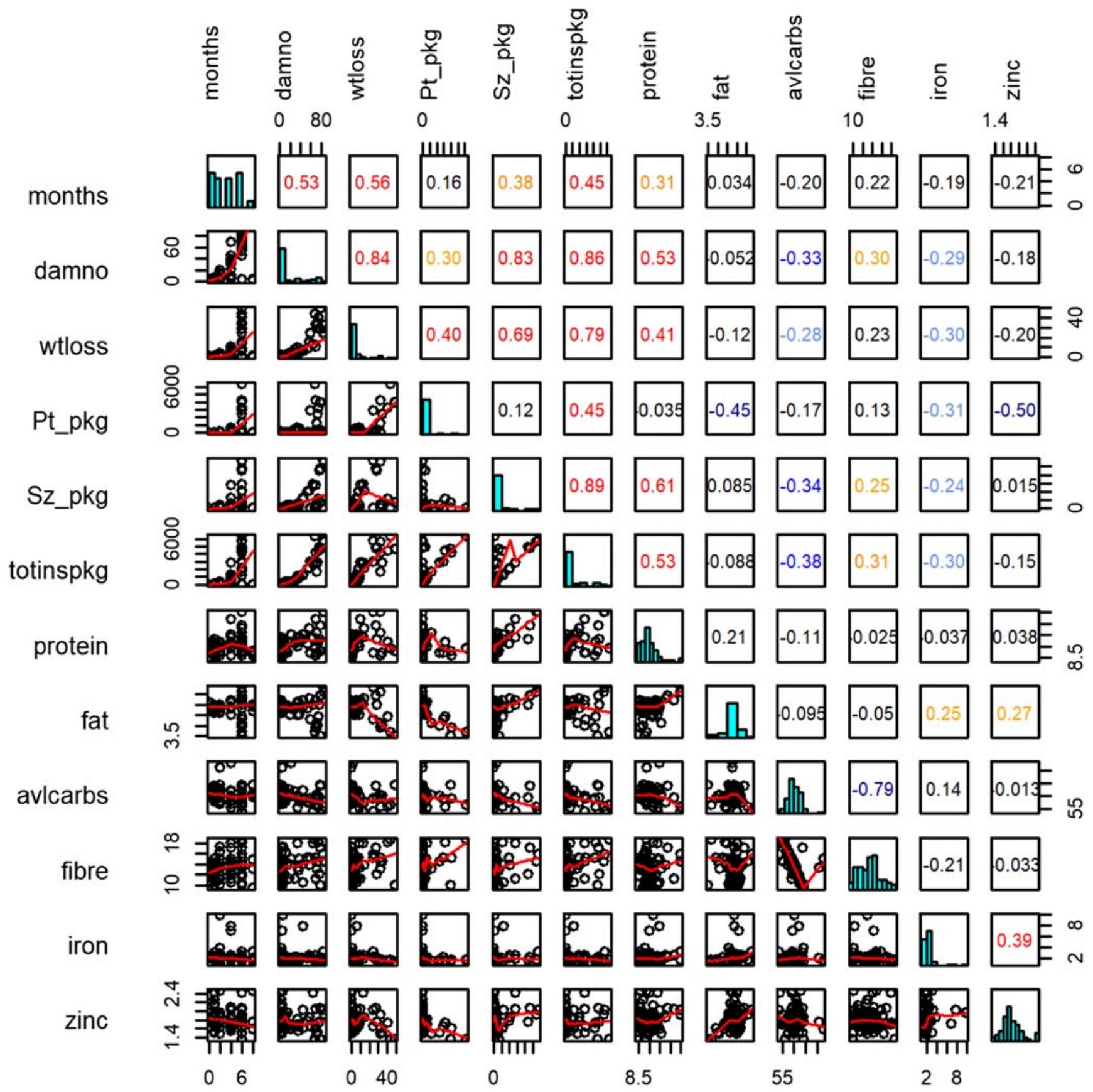

Fig. 8 Pairs plot and Spearman's rank correlations of relationships between the different storage insects and nutrients in white maize grain [Spearman's rank correlation critical values for $N=69$ are $p=0.05 *$ $0.237 ; p=0.01 * 0.309 ; p=0.001 * * * 0.390$, the significantly positive correlations are shown in shades of yellow $<$ red, and the significantly

negative correlations in blue $;$ abbreviations $=$ months $=$ storage duration; damno = percentage damaged grain (by number); wtloss = percentage grain weight loss; Pt pkg = total $\mathrm{P}$. truncatus/ $\mathrm{kg} ; \mathrm{Sz} . \mathrm{pkg}=$ total $\mathrm{S}$. zeamais/ $\mathrm{kg}$; totins = total number of insects/ $\mathrm{kg}$; avlcarbs = available carbohydrates]

All the carotenoid variables were negatively correlated with increasing storage duration (beta-cryptoxanthin (Bcrypt; $\mathrm{p}<0.001$ ); all-trans beta-carotene (alltransBC; $\mathrm{p}<$ 0.001 ); cis beta-carotene (cisBC; $\mathrm{p}<0.001$ ); total pVA (totprova; $\mathrm{p}<0.001$ ); lutein (lutein; $\mathrm{p}<0.01$ ); total carotenoids (totcarot; $\mathrm{p}<0.01$ ); zeaxanthin (zeaxanthin; $\mathrm{p}<0.05)$ ); highlighting their instability over time during grain storage (Fig. 10), whether the grain was infested with insects or not (Fig. 5). Increasing percentage grain weight loss was correlated with a decrease in: all trans beta-carotene (alltransBC; $\mathrm{p}<0.05$ ), cis beta-carotene (cisBC; $\mathrm{p}<0.05$ ), and total pro-Vitamin A (totprova; $\mathrm{p}<$ 


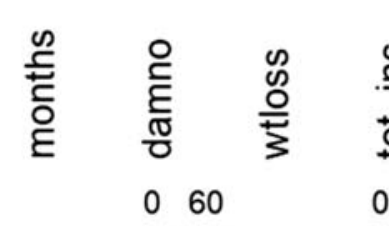

months

damno

wtloss

tot_ins

$\mathrm{mc}$
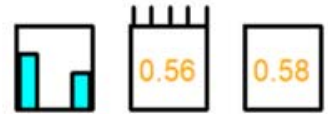

8
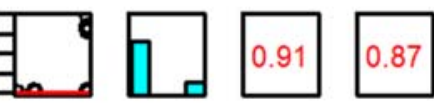

шسल
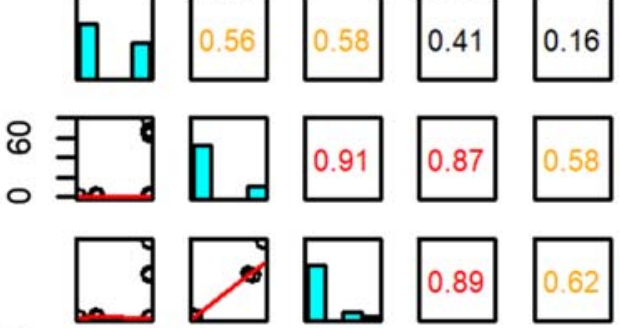

용
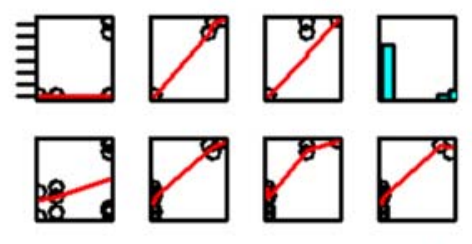

N
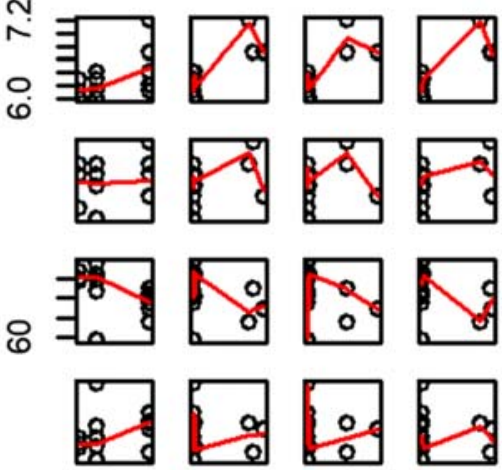

fibre
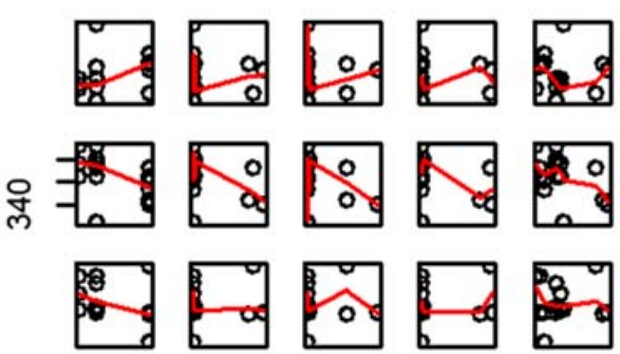

iron
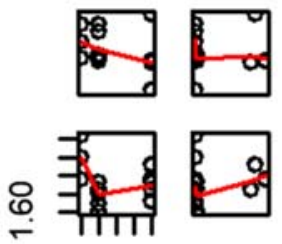

03

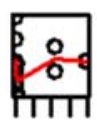

030
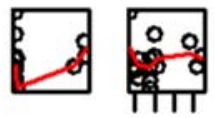

11.5

Fig. 9 Pairs plot and Spearman's rank correlations of relationships between storage insect damage factors and nutrients in pro-Vitamin A biofortified orange maize grain [Spearman's rank correlation critical values for $N=15 ; p=0.05 * 0.521 ; p=0.01 * * 0.654 ; p=0.001 * * *$ 0.779 , the significantly positive correlations are shown in shades of

0.05) (Fig. 10). All the carotenoids (lutein, zeaxanthin, beta-cryptoxanthin, cis beta-carotene, all trans beta-carotene, total carotenoids, total pro Vitamin A) were significantly $(p<0.05)$ positively correlated with each other (Fig. 10).

\section{(⿻)}

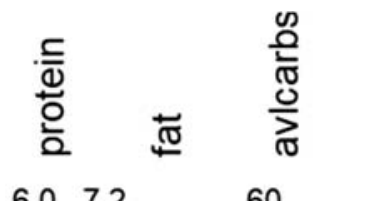

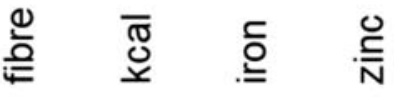
$6.07 .2 \quad 60$

шس
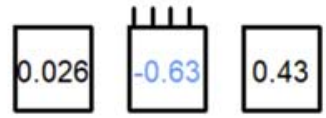

340 1.60
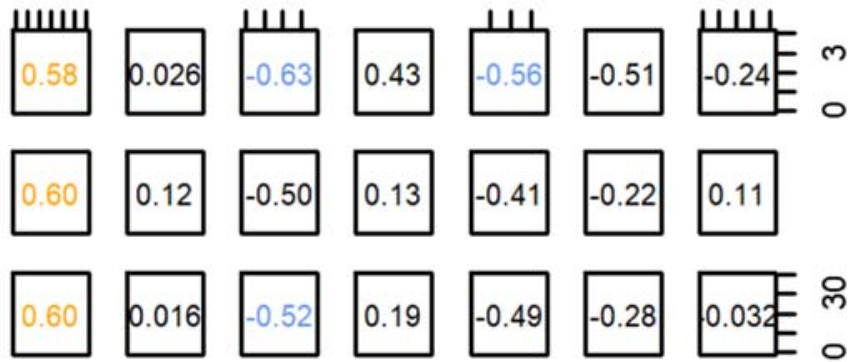

0.19

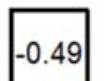

\section{$-0.28$}
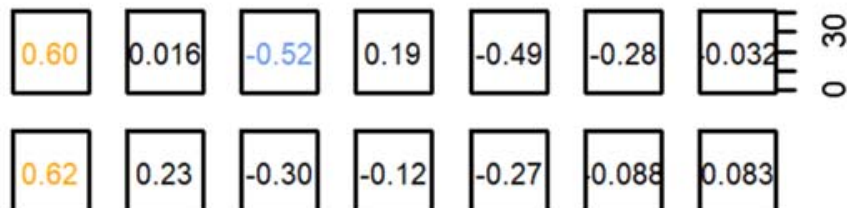

0.08
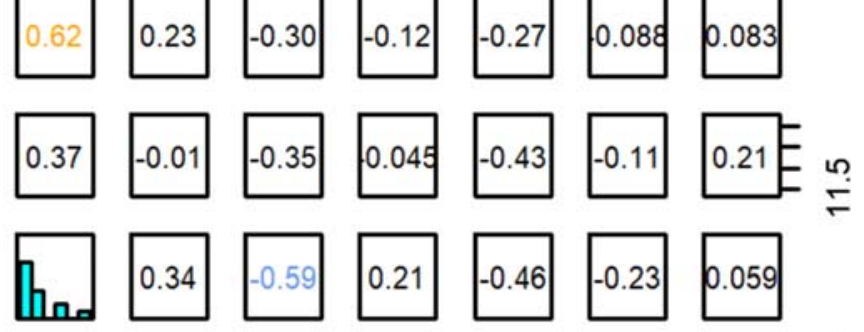

$-0.23$
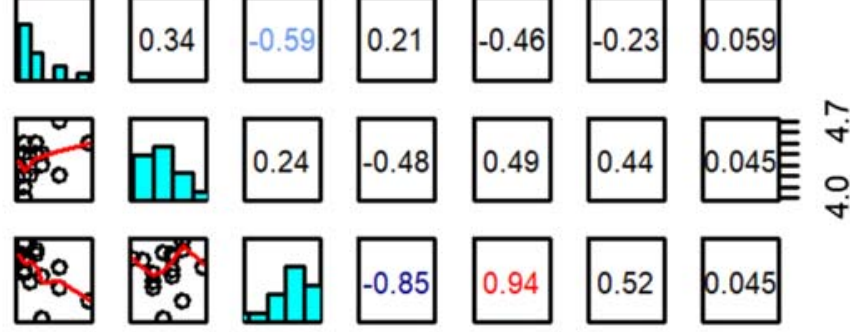

0.045
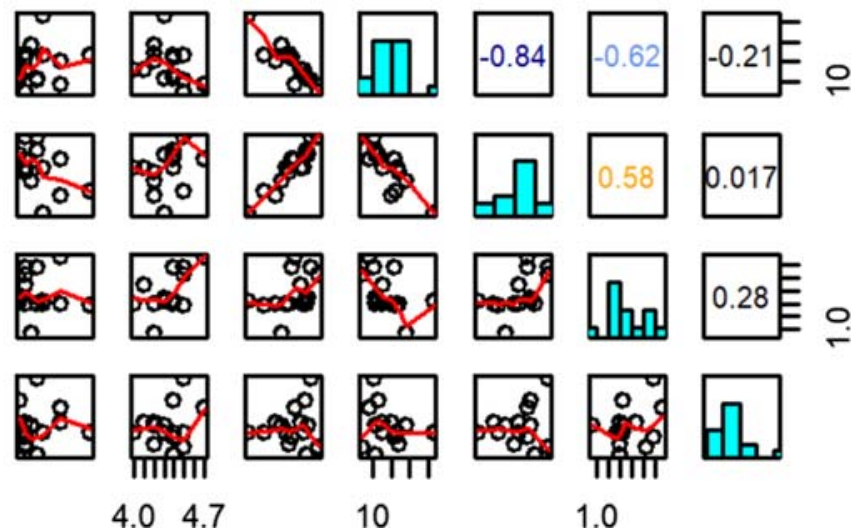

10

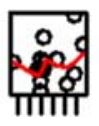

1.0

yellow $<$ red, and the significantly negative correlations in shades of blue; abbreviations: months $=$ storage duration; damno = percentage damaged grain (by number); wtloss = percentage grain weight loss; tot_ins = total number of insects $/ \mathrm{kg} ; m c=$ percentage grain moisture content; avlcarbs = available carbohydrates; $k c a l=$ energy $(\mathrm{kcal} / 100 \mathrm{~g})]$

\subsubsection{Shifts in nutrient contents in insect-infested cowpea} grain

The relationships between insect damage variables and nutritional composition, moisture content and storage duration in cowpea 


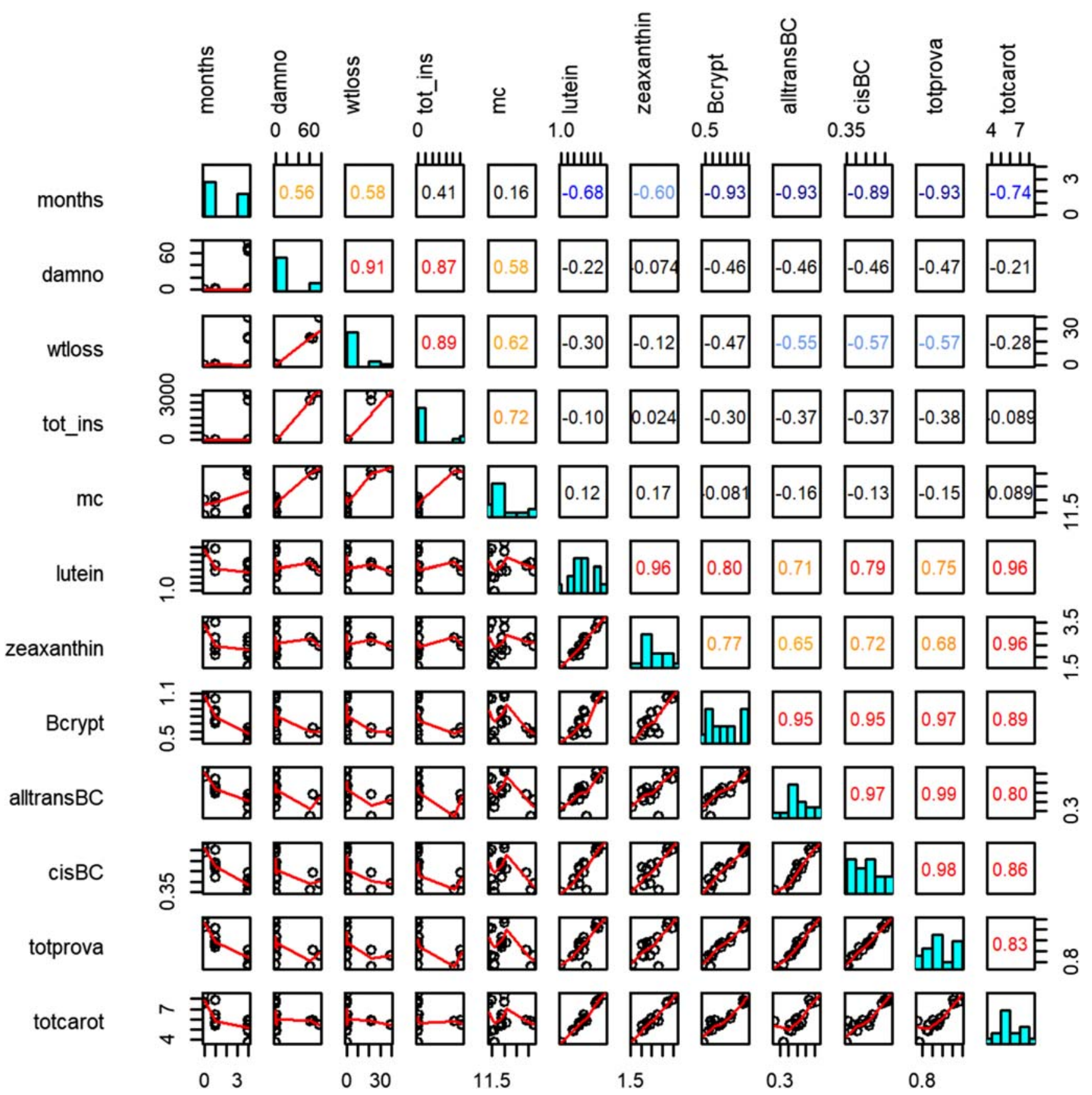

Fig. 10 Pairs plot and Spearman's rank correlations of relationships between storage insect damage factors and carotenoids in pro-Vitamin A biofortified orange maize grain [Spearman's rank correlation critical values for $N=15 ; p=0.05 * 0.521 ; p=0.01 * * 0.654 ; p=0.001 * * *$ 0.779 , the significantly positive correlations are shown in shades of yellow $<$ red, and the significantly negative correlations in shades of blue;

abbreviations: months $=$ storage duration; damno = percentage damaged grain (by number); wtloss = percentage grain weight loss; tot_ins $=$ total number of insects/ $\mathrm{kg} ; m \mathrm{c}=$ percentage grain moisture content; the carotenoids shown are lutein, zeaxanthin, beta-cryptoxanthin, trans betacarotene, cis beta-carotene, total pro Vitamin A, total carotenoids]

grain are visualised in the pairs plot in Fig. 11. In the cowpea samples, storage duration (months) was not positively correlated with increasing percentage damaged grain, but was correlated with the percentage grain weight loss (wtloss; $\mathrm{p}<0.05$ ), and grain moisture content $(\mathrm{mc} ; \mathrm{p}<0.05)$, as well as with protein (protein; $\mathrm{p}<0.001$ ) and iron (iron; $\mathrm{p}<0.01$ ) content, and negatively with fibre content (fibre; $\mathrm{p}<0.01$ ) (Fig. 6).

Percentage damaged grain and percentage weight loss were negatively correlated with the available carbohydrate (avlcarbs; $\mathrm{p}<0.05$ ) and fibre (fibre; $\mathrm{p}<0.05$ ) 


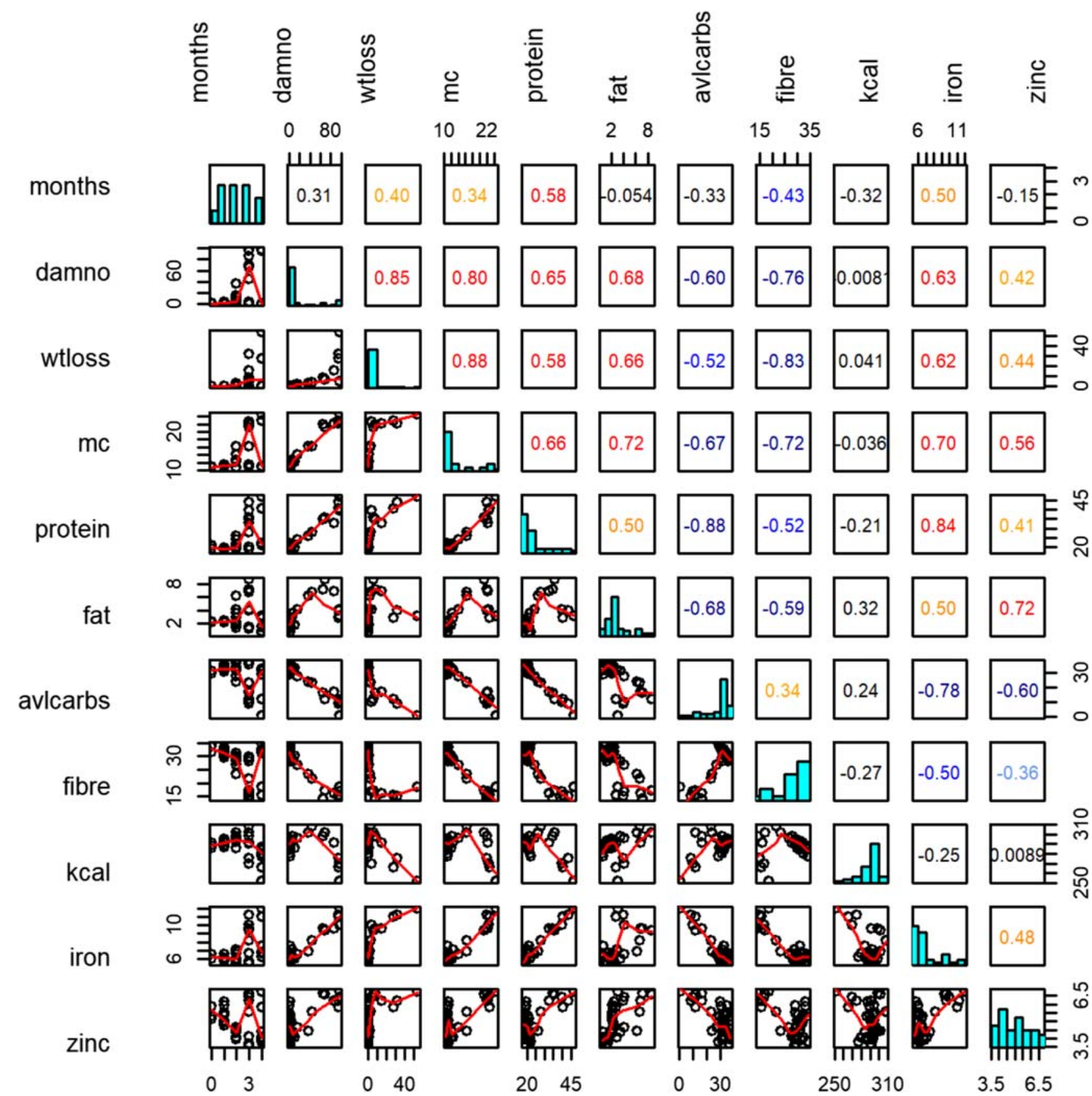

Fig. 11 Pairs plot and Spearman's rank correlations of relationships between storage insect damage factors and nutrients in stored cowpea grain [Spearman's rank correlation critical values for $N=36$ are $p=$ $0.05 * 0.33 ; p=0.01 * * 0.427 ; p=0.001 * * * 0.533$, the significantly positive correlations are shown in shades of yellow $<$ red, and the

significantly negative correlations in shades blue; abbreviations $=$ months = storage duration; damno = percentage damaged grain (by number); wtloss = percentage grain weight loss; tot_ins = total number of insects $/ \mathrm{kg} ; m c=$ percentage grain moisture content; avlcarbs = available carbohydrates; $k c a l=$ energy $(\mathrm{kcal} / 100 \mathrm{~g})]$

content of the cowpea grains. As with both types of maize grain studied, insect infestation in the stored cowpea grain was positively correlated with increasing protein content (protein; $\mathrm{p}<0.001)$ and increasing moisture content $(\mathrm{mc} ; \mathrm{p}<0.001)$ of the remaining material. Additionally, insect infestation variables were also significantly positively correlated with increasing fat (fat; $p<0.001$ ), iron (iron; $p<0.001$ ), and zinc (zinc; $\mathrm{p}<0.05$ ) content. No correlation was found between the insect damage variables and the energy (kcal) content of the cowpea grains.

Significant correlations between insect infestation and nutrients could be used to develop a cowpea storage loss prediction calculation tool, a prototype example is shown in Supplemental Tool 2. 


\section{Discussion and conclusion}

\subsection{Impact of insect infestation on nutrient content of stored maize and cowpea grain}

The results of our controlled laboratory bioassays can be summarised as follows:

1. Most nutrients in stored maize and cowpea grain remained stable over time in the absence of insect infestation with the exception of carotenoids, which degraded over the storage period

2. The three insect infestation variables measured (percentage damaged grains, percentage weight loss, and total number of insects per $\mathrm{kg}$ ) were correlated

3. Correlations were found between insect infestation level (measured as percentage damaged grains, percentage weight loss, or total insects per $\mathrm{kg}$ ) and some nutrients

a. Insect infestation level was negatively correlated with carbohydrate proportion as the storage insects consumed the carbohydrate over time

b. Insect infestation level was positively correlated with protein proportion as the carbohydrate proportion dropped

c. Insect infestation level was positively correlated with moisture content

d. Insect infestation level was largely independent of carotenoid quantities as they predictably degrade over time whether grain is infested or not

e. Changes in the proportion of fat, iron and zinc in insect-infested stored grain are insect species- and crop-specific.

The higher protein concentration associated with $S$. zeamais compared to $P$. truncatus might be due to different larval feeding patterns or other physiological and/or behavioural aspects. While $S$. zeamais larvae feed preferentially on the protein-poor endosperm (Sharifi 1972; Sharifi and Mills 1971; authors' laboratory investigations), P. truncatus larvae also feed heavily on the protein and fat-rich germ (Ramirez and Silver 1983; authors' laboratory investigations) (Supplemental Fig. S1), and therefore metabolise a higher relative proportion of the protein and fat present in the original grain. As a result, the residual uneaten material tends to be enriched in proteins over time when the infestation is mainly caused by $S$. zeamais. Additionally, more of the developing larvae of $S$. zeamais than of $P$. truncatus remain inside feeding tunnels in the grain despite the sieving process, and if numerous, their presence may affect the nutrient composition of the complete remaining grain product. Extensive tunnelling damage is caused by the multiple $P$. truncatus larvae per infested grain (Ramirez and Silver 1983), causing the grain to be more likely to break into small pieces. This may result in greater removal of $P$. truncatus than $S$. zeamais larvae during sieving. As a $S$. zeamais female only lays a single egg which it seals with an egg-plug in the cavity chewed into each cereal grain (Haines et al. 1991), the developing larva tends to leave the outer structure of the grain largely intact.

Similarly, increasing insect damage on stored cowpea led to decreased carbohydrate concentration and increasing concentration of protein, fat, iron, zinc and moisture. Cowpea has a more homogenous distribution of nutrients compared to maize grains. Thus, the increasing concentration of protein, fat and minerals in insect-infested cowpea is more likely to be linked to the presence of the protein, fat, iron and zinc-rich larval and pupal stages of the bruchid C. maculatus, which remain immobile and trapped inside the grains despite sieving (or winnowing), than to differential consumption of grain parts by the insects. In contrast, the iron content decreased in white and pVA biofortified orange maize as insect damage increased. The unusually low carbohydrate values for cowpea probably result from the calculation used to derive carbohydrate by difference rather than direct measurement in the nutrient analysis, with some constituents being categorised as dietary fibre despite being carbohydrate (e.g. some resistant starches) (Haralampu, 2000).

While grain with a higher protein concentration would appear to be a positive nutritional outcome, insect infestation resulted in a higher concentration of protein but in a smaller overall amount of food, giving a net reduction in the overall amount of protein available (Fig. 12).

Our study confirmed the instability during grain storage of the nutritionally valuable carotenoids present in pVA biofortified orange maize, even without infestation (Mugode et al. 2014; De Moura et al. 2015; Bechoff and DhuiqueMayer 2017; Taleon et al. 2017). The pVA biofortified orange maize also sustained higher insect damage by 4 months' storage (69\% damaged grains) compared to the white hybrid maize grain (37\% damaged grains), despite identical numbers

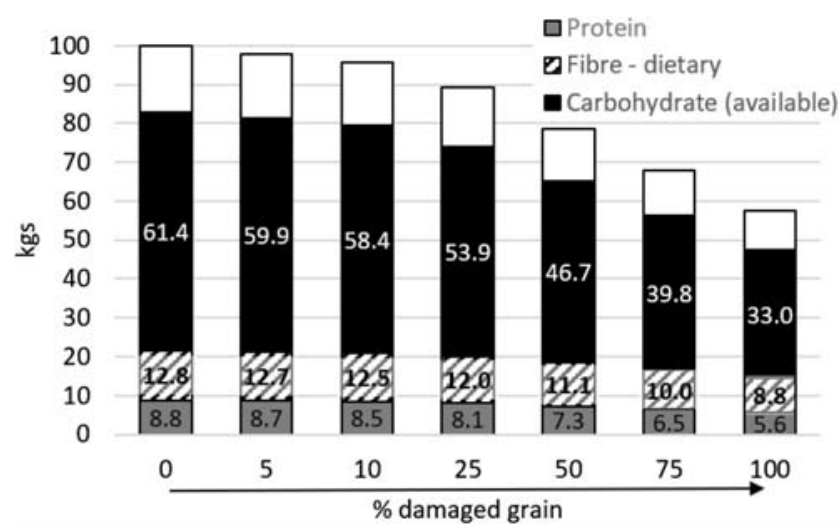

Fig. 12 Example of the quantity of protein, fibre and carbohydrate remaining in a stock of $100 \mathrm{~kg}$ of white maize grain at different insect infestation levels 
and species of insects being initially introduced. High susceptibility to storage insect damage combined with carotenoid instability during typical smallholder farmer postharvest drying and storage activities (Lividini and Fiedler 2015), could limit the potential nutritional impact of $\mathrm{pVA}$ biofortified orange maize varieties. Improved grain storage practice and technologies such as hermetic grain storage bags can limit insect infestation. Recent research has shown the addition of oxygen scavengers to hermetic storage bags reduced carotenoid loss in pVA orange maize during storage durations of up to 6 months (Nkhata et al. 2019).

\subsection{Applicability of the work}

In our study the crops were grown, harvested, threshed and dried by smallholder farming households. However, the study was laboratory-based and the grain stored under constant temperature and relative humidity conditions and in jars, therefore differing from farmer-stored grain which would experience varying temperature and relative humidity during the day and over seasons. In farmers' stores, insects disperse when high population densities are reached or food resources depleted, but could not disperse from our trial jars. Additionally, farmer-stored cereal and legume grains may be attacked by a wider range of insect species and/or by fungi and rodents. A similar experiment could evaluate the nutritional effect of rodent and fungal damage during crop storage. Rodents preferentially consume the grain's germ (Justice and Bass 1979), cause contamination and by damaging packaging generate spillages (Mdangi et al. 2013). Given that mould developed in our cowpea and maize grain at the high insect damage levels, fungi which consume fat and carbohydrate for energy (Reed et al. 2007), will also have contributed to the nutrient changes. The fungi may also produce toxic secondarymetabolites and contaminate the grain with mycotoxins. In situations where food safety standards are implemented such contamination, if above the agreed maximum tolerable level, will result in a $100 \%$ loss of all the grain and the nutrients it contained. In more typical SSA domestic food systems, where food safety standards are rarely monitored or enforced and the bulk of the population consume their own produce, grain infected by fungi may not be removed resulting in the consumption of grain with reduced nutritional content and the harmful effects of mycotoxin contamination (see Shephard 2008, Ayalew et al. 2016, Omotayo et al., 2019 for further discussion).

Farm-level storage studies are needed to explore how our laboratory findings relating to the changes which occurred in the content and quantity of nutrients during storage of different grains, with different insect types and infestation levels, over different storage durations, compare to those experienced in farm-level stored grain. Further studies could also explore how the effect of storage insect-infestation on nutrient content differs between varieties and production locations, as variety and environmental factors such as soil quality and altitude are known to affect the nutritional composition of crops (Nuss and Tanumihardjo 2010; Charrondiere et al. 2013). These and other studies could further develop and validate our prototype grain storage nutrient loss calculation tools (Supplemental Tool 1 and 2), which require a user to input the percentage insect damage, to obtain a calculation of the remaining quantity and proportions of nutrients in their insect-infested stored grain.

In insect-infested stored grain, the percentage damaged grain and percentage grain weight loss are correlated. However, the relationship between them differs by grain and infesting insect species. For example, in maize a 5\% grain weight loss during storage equates to about $30 \%$ of grains having insect holes in them ( $\sim 30 \%$ damaged grains), while for cowpeas a $5 \%$ grain weight loss during storage equates to about 60\% damaged grains (Supplemental Fig. S2).

When preparing grain for consumption, some quality screening occurs. Grain is typically winnowed prior to being milled or cooked, this removes the trash portion (which contains insect waste, body parts, and grain dust generated during insect boring) which is not usually consumed. Additionally, for beans, cowpeas and other legumes in many SSA countries the damaged grains from a batch are removed by hand-picking (pers. obs.). In these cases where damaged legume grains are manually removed, the 'percentage damaged grains' will then represent the portion of the grain that is lost from human consumption. For example, cowpea can suffer a 5\% grain weight loss due to storage insect infestation but this may mean $60 \%$ of the grains are damaged and thus removed from the batch and not consumed. Therefore, $60 \%$ of all the nutrients would be lost from direct human consumption due to removal of damaged grains. Meanwhile, remaining early-stage infested grains, where damage is not easily externally visible, would be consumed rather than manually removed but contain less carbohydrate (and slightly increased concentrations of protein, fat, zinc and iron) compared to perfectly undamaged cowpea grain. Conversely, if a batch of a grain is winnowed, milled and processed into food without removal of damaged grains, as typically happens with many cereal grains in SSA countries, then the percentage grain weight loss figure will equate to the percentage weight of grain lost from human consumption, but the overall quality of the grain would also be reduced. However, a total loss can occur if stored grain is damaged by insects to such a degree that it becomes extremely mouldy, unappealing, and unfit for human consumption, although not all grains may exhibit visible insect damage.

A study in Tanzania found that although $>90 \%$ of their sample of 120 households manually sorted out their insectdamaged and mouldy maize grains prior to storing the grain, $45 \%$ of these households then consumed these insectdamaged and mouldy maize grains (Kimanya et al. 2008). 
Improving our understanding of consumers' behavioural responses and attitudes regards different types of postharvest quality deterioration is crucial for more accurately understanding and reducing the nutritional impacts of postharvest loss.

\subsection{Further work and conclusions}

Further work could validate and refine our findings and the prototype nutrient grain storage loss calculation tool and investigate the impact of different insect species and combinations on the nutrient composition of different stored staple crops and varieties of them. More detailed work could investigate the effect of insect infestation on essential amino acids (i.e. lysine and threonine which are limiting in cereals; methionine and tryptophan which are limiting in legumes (FAO 1983)), and protein quality. Future studies could also quantify the extent to which the insect bodies themselves affect the grain product's nutrient composition when they are left in the grain after sieving or winnowing. Farm-level storage studies are needed to explore how similar our laboratory findings on the nutritional effect of insect-infestation are to those experienced in smallholder farmers' grain stores. Finally, it is important to understand more about consumer behaviour in response to different types of infestation - when, where, why and which damaged grains are or are not consumed. By quantifying the influence of insect infestation on the nutritional properties of stored grain we are better placed to understand how household nutrition and food security are affected by insect-mediated storage losses. In addition to the reduction in the quantity of grain stocks available for consumption due to insect damage, the protein-carbohydrate ratios and iron content can change significantly in insect-infested stored grain, with implications for the health of some of the most vulnerable groups of people.

Acknowledgements This research was supported by funding from the UK's Department for International Development (DFID) Innovative Metrics and Methods for Agriculture and Nutrition Actions (IMMANA) initiative as one part of the Nutritional Postharvest Loss Estimation Methodology (NUTRI-P-LOSS) project. We gratefully acknowledge: the assistance of Sarah Westby, Evie Keane and Aditya Parmar during some of the insect grain damage assessments; Jonathon Griffin's team at the Kent Scientific Services laboratory who conducted the food proximate and mineral analyses; the Plants for Health Institute, North Carolina State University team who analysed the carotenoids in the pVA biofortified orange maize samples; the University of Zimbabwe crop postharvest team who sourced and supplied the grain; and Natalie Morley for help with management and set-up of facilities. We are also grateful to Stephen Young for advice and support with the statistical analyses, Suzanne Nielsen and Mario Ferruzzi for discussions on nutritional aspects, Brighton Mvumi for discussions during the trial planning stages, Aurelie Bechoff for project coordination, and two anonymous reviewers for their constructive comments. Any opinions and conclusions expressed, or omissions are those of the authors. The views expressed in this paper do not necessarily reflect the views of the donor.

\section{Compliance with ethical standards}

Conflict of interest The authors declare that they have no conflict of interest.

Open Access This article is licensed under a Creative Commons Attribution 4.0 International License, which permits use, sharing, adaptation, distribution and reproduction in any medium or format, as long as you give appropriate credit to the original author(s) and the source, provide a link to the Creative Commons licence, and indicate if changes were made. The images or other third party material in this article are included in the article's Creative Commons licence, unless indicated otherwise in a credit line to the material. If material is not included in the article's Creative Commons licence and your intended use is not permitted by statutory regulation or exceeds the permitted use, you will need to obtain permission directly from the copyright holder. To view a copy of this licence, visit http://creativecommons.org/licenses/by/4.0/.

\section{References}

Adams, J. M., \& Schulten, G. G. M. (1978). Chapter VI. Standard measurement techniques. pp 90. In K. H. Harris \& C. J. Lindblad (Eds.), Postharvest grain loss assessment methods American Association of Cereal Chemists.

Affognon, H., Mutungi, C., Sanginga, P., \& Borgemeister, C. (2015). Unpacking postharvest losses in sub-Saharan Africa: A meta-analysis. World Development, 66, 49-68.

Agrawal, N. S., Christensen, C. M., \& Hodson, A. (1957). Grain storage fungi associated with the granary weevil. Journal of Economic Entomology, 50, 659-663.

Ayalew, A., Hoffmann, V., Lindahl, J., \& Ezekiel, C.N. (2016). The role of mycotoxin contamination in nutrition: The aflatoxin story. pp. 98-114. In: Covic, N. and Hendriks, S.L. (eds), Achieving a nutrition revolution for Africa: The road to healthier diets and optimal nutrition. ReSAKSS Annual Trends and Outlook Report 2015. Washington, DC: IFPRI.

Baldi, G., Fossati, G., Ranghino, F., \& Fantone, G. C. (1977). Conservazione del riso: variazioni in contenuto proteico, frazioni proteiche, composizione amminoacidica. Riso, 26, 253-265.

Bechoff, A., \& Dhuique-Mayer, C. (2017). Factors influencing micronutrient bioavailability in biofortified crops. Annals of the New York Academy of Sciences, 1390, 74-87.

Boxall, R.A. 1986. A critical review of the methodology for assessing farm-level grain losses after harvest (G191). http://gala.gre.ac.uk/ 10793/

Burt, A. J., Grainger, C. M., J., Young, C., Shelp, B. J., Lee, E. A. (2010). Impact of postharvest handling on carotenoid concentration and composition in high-carotenoid maize (Zea mays L.) kernels. Journal of Agricultural and Food Chemistry, 58(14), 8286-8292

Charrondiere, U. R., Stadlmayr, B., Rittenschober, D., Mouille, B., Nilsson, E., Medhammar, E., Olango, T., Eisenwagen, S., Persijn, D., Ebanks, K., Nowak, V., Du, J., \& Burlingame, B. (2013). FAO/ INFOODS food composition database for biodiversity. Food Chemistry, 140, 408-412.

Compton, J. A. F., Floyd, S., Magrath, P. A., Addo, S., Gbedevi, S. R., Agbo, B., Bokor, G., Amekupe, S., Motey, Z., Penni, H., \& Kumi, S. (1998). Involving grain traders in determining the effect of postharvest insect damage on the price of maize in African markets. Crop Protection, 17, 483-489.

Core Team, R. (2018). R: A language and environment for statistical computing. The R Foundation for statistical computing. Vienna: Austria. 
De Lima, C. P. F. (1979). Appropriate techniques for use in the assessment of country loss in stored produce in the tropics. Tropical Stored Products Information, 38, 15-19.

De Mendiburu, F. (2019). Agricolae: Statistical procedures for agricultural research. $R$ package version, 1, 3-1 https://CRAN.R-project.org/ package $=$ agricolae.

De Moura, F. F., Miloff, A., \& Boy, E. (2015). Retention of Provitamin A carotenoids in staple crops targeted for biofortification in Africa: Cassava, maize and sweet potato. Critical Reviews in Food Science and Nutrition, 55(9), 1246-1269.

Dejene, M., Yuen, J., \& Sigvald, R. (2006). Effects of storage methods, storage time and different agro-ecological zones on chemical components of stored sorghum grain in Hararghe, Ethiopia. Journal of Stored Products Research, 42, 445-456.

Demianyk, C., \& Sinha, R. (1988). Bioenergetics of the larger grain borer, Prostephanus truncatus (Horn) (Coleoptera: Bostrichidae), feeding on corn. Annals of the Entomological Society of America, 81, 449459.

Dobie, P., Haines, C. P., Hodges, R. J., Prevett, P. F., \& Rees, D. P. (1991). Insects and arachnids of tropical stored products: Their biology and identification (2nd ed.103pp). Chatham, UK: Natural Resources Institute.

FAO. (1983). Post-harvest losses in quality of food grains. In $F A O$ food and nutritional paper 29 (103 pp). FAO: Rome.

FAO. (2013). Food wastage footprint: Impacts on natural resources. Rome: FAO.

FAO, IFAD, UNICEF, WFP and WHO. (2017). The State of Food Security and Nutrition in the World 2017. Building resilience for peace and food security (132pp). FAO: Rome.

FAO, IFAD, UNICEF, WFP and WHO. (2019). The State of Food Security and Nutrition in the World 2019. Safeguarding against economic slowdowns and downturns (239pp). FAO: Rome.

Foresight Review. (2011). The Future of Food and Farming: Challenges and choices for global sustainability, 211pp. London: Government Office for Science.

Fourar-Belaifa, R., Fleurat-Lessard, F., \& Bouznad, Z. (2011). A systemic approach to qualitative changes in the stored wheat ecosystem: Prediction of deterioration risks in unsafe storage conditions in relation to relative humidity level, infestation by Sitophilus oryzae (L.), and wheat variety. Journal of Stored Products Research, 47, 48-61.

Francis, B. J., \& Adams, J. M. (1980). Loss of dry matter and nutritive value in experimentally infested wheat. Tropical Science, 22, 55-68.

Godfray, H. C., \& Garnett, T. (2014). Food security and sustainable intensification. Philosophical Transactions of the Royal Society B, 369, 20120273

Golob, P., Moss, C., Devereau, A., Goodland, A. D., Tran, B.M.D., Andan, F. H., Atarigya, J., Annan, N.T., Osei-Yaw, A., Plahar, W.A., Appleby, J., Credland, P.F., Ayuba, I., Seini, S., \& Bediako, J. (1999). Improvements in the storage and marketing quality of grain legumes. Final technical report for the NRI project R6503, 56pp., natural resources institute, Chatham, UK.

Gregory, P. J., Johnson, S. N., Newton, A. C., \& Ingram, J. S. (2009). Integrating pests and pathogens into the climate change/ food security debate. Journal of Experimental Botany, 60(10), 2827-2838.

Gustavsson, J., Cedeberg, C., Sonesson, U., van Otterdijk, R., \& Meybeck, A. (2011). Global food losses and food waste: Extent, causes and prevention (37pp). Rome: FAO.

Haines, C. P., Dobie, P., Hodges, R. J., Prevett, P. F., \& Rees, D. P. (Eds.). (1991). Insects and arachnids of tropical stored products: Their biology and identification: A training manual (p. 46). Chatham, Kent, UK: Natural Resources Institute.

Haralampu, S. G. (2000). Resistant starch - a review of the physical properties and biological impact of $\mathrm{RS}_{3}$. Carbohydrate Polymers, 41, 285-292.
Hodges, R. J. (2013). How to assess postharvest cereal losses and their impact on grain supply: Rapid weight loss estimation and the calculation of cumulative cereal losses with the support of APHLIS (121 pp). UK: Natural Resources Institute.

Hodges, R. J., \& Stathers, T. E. (2012). Training manual for improving grain postharvest handling and storage (246 pp). Rome: World Food Programme https:/www.wfp.org/content/p4p-trainingmanual-improving-grain-postharvest-handling-and-storage .

Hodges, R. J., \& Stathers, T. E. (2013). Facing the food crisis: How African smallholders can reduce postharvest cereal losses by supplying better quality grain. Outlooks on Pest Management, 24, 217-221.

Hodges, R.J., Benard, M., \& Rembold, F. (2014). APHLIS - Postharvest cereal losses in sub-Saharan Africa, their estimation, assessment and reduction. European Commission JRC Technical Reports. 177 pp.

Hoffman, V., \& Gatobu, K. M. (2014). Growing their own: Unobservable quality and the value of self-provisioning. Journal of Development Economics, 106, 168-178.

Irabagon, T. A. (1959). Rice weevil damage to stored corn. Journal of Economic Entomology, 52(6), 1130-1136.

Jones, M., Alexander, C., \& Lowenberg-DeBoer, J. (2014). A simple methodology for measuring profitability of on-farm storage pest management in developing countries. Journal of Stored Products Research, 58, 67-76.

Jones, M., Alexander, C., Widmar, N., Ricker-Gilbert, J., \& LowenbergDeBoer, J. M. (2016). Do insect and mould damage affect maize prices in Africa? Evidence from Malawi. Modern Economy, 7, $1168-1185$.

Jones, M. S., Alexander, C. E., \& Smith, B. (2018). Economic consequences of post-harvest insect damage in Rwandan common bean markets. Crop Protection, 104, 92-100.

Jood, S., \& Kapoor, A. C. (1992). Biological evaluation of protein quality of wheat as affected by insect infestation. Food Chemistry, 45(3), $169-174$.

Justice, O. L., \& Bass, L. N. (1979). Principles of seed storage. 275 pp. Beccles and London: Castle House Publications.

Kadjo, D., Ricker-Gilbert, J., \& Alexander, C. (2016). Estimating price discounts for low-quality maize in SSA: Evidence from Benin. World Development, 77, 115-128.

Kean, E. G., Hamaker, B. R., \& Ferruzzi, M. G. (2008). Carotenoid bioaccessibility from whole grain and degermed maize meal products. Journal of Agricultural and Food Chemistry, 56, 9918-9926.

Kimanya, M. E., de Meulenaer, B., Tiisekwa, B., Ndomondo-Sigonda, M., Devlieghere, F., van Camp, J., \& Kolsteren, P. (2008). Cooccurrence of fumonisins with aflatoxins in home-stored maize for human consumption in rural villages of Tanzania. Food Additives and Contaminants Part A Chemistry Analysis Control Exposure and Risk Assessment, 25(11), 1353-1364.

Kodicek, E., Brauder, R., Kon, S. K., \& Mitchell, K. G. (1959). The availability to pigs of nicotinic acid in tortilla baked from maize treated with lime-water. British Journal of Nutrition, 13, 363-384.

Ladisch, R. K., Suter, M. S. A., \& Froio, G. F. (1968). Sweat gland carcinoma produced in mice by insect quinones. Proceedings of the Pennsylvania Academy of Science, 42, 87-91.

Langyintuo, A. S., Lowenberg-DeBoer, J., Faye, M., Lambert, D., Ibro, G., Moussa, B., Kergna, A., Kushwaha, S., Musa, S., \& Ntoukam, G. (2003). Cowpea supply and demand in west and Central Africa. Field Crops Research, 82(2-3), 215-231.

Langyintuo, A. S., Ntoukam, G., Murdock, L., Lowenberg-DeBoer, L., \& Miller, D. J. (2004). Consumer preferences for cowpea in Cameroon and Ghana. Agricultural Economics, 30(3), 203-213.

Lividini, K., \& Fiedler, J. L. (2015). Assessing the promise of biofortification: A case study of high provitamin A maize in Zambia. Food Policy, 54, 65-77.

Lopez-Verge, S., Barroeta, A. C., Riudavets, J., \& Rodriguez-Jerez, J. J. (2013). Utilization of Sitophilus zeamais (Motschulsky) larvae as a 
dietary supplement for the production of broiler chickens. Proceedings of the Nutrition Society, 72, E315.

Mdangi, M., Mulungu, L. S., Massawe, A. W., Eiseb, S., Tutjavi, V., Kirsten, F., Mahlaba, T., Malebane, P., Maltitz, E. V., Monadjem, A., Dlamini, N., Makundi, R. H., \& Belmain, S. R. (2013). Assessment of rodent damage to stored maize (Zea mays L.) on smallholder farms in Tanzania. International Journal of Pest Management, 59(1), 55-62.

Mishili, F. J., Fulton, J., Shehu, M., Kushwaha, S., Marfo, K., Jamal, M., Chergna, A., \& Lowenberg-DeBoer, J. (2007). Consumer preferences for quality characteristics along the cowpea value chain in Nigeria, Ghana and Mali. In Working Paper \#06-17. Department of Agricultural Economics: Purdue University Available at http:// ageconsearch.umn.edu/bitstream/28684/1/wp060017.pdf.

Mishili, F. J., Temu, A., Fulton, J., \& Lowenberg-DeBoer, J. (2011). Consumer preferences as drivers of the common bean trade in Tanzania: A marketing perspective. Journal of International Food \& Agribusiness Marketing, 23(2), 110-127.

Mugode, L., Ha, B., Kaunda, A., Sikombe, T., Phiri, S., Mutale, R., Davis, C., Tanumihardjo, S., \& de Moura, F. F. (2014). Carotenoid retention of biofortified provitamin A maize (Zea mays L.) after Zambian traditional methods of milling, cooking and storage. Journal of Agricultural and Food Chemistry, 62(27), 6317-6325.

Murthy, N. K., \& Kokilavani, R. (1980). Biodeterioration of stored, insect infested jowar and ragi (Sorghum vulgare, Eleusine coracana (millets), India). Indian Journal of Nutrition and Dietetics, 17, 201.

Mvumi, B.M. \& Stathers, T.E. (2014). Food security challenges in subSaharan Africa: The potential contribution of postharvest skills, science and technology in closing the gap. In: Proceedings of the 11th IWCSPP, 24-28 November, 2014, Chiang Mai, Thailand, Arthur, F.H., Kenganpanich, R., Chayaprasert, W., Suthisut, D., (Eds.), 32-43.

Naves, M. M. V., de Castro, M. V. L., de Mendonca, A. L., Santos, G. G., \& Silva, M. S. (2011). Corn germ with pericarp in relation to whole corn: Nutrient contents, food and protein efficiency, and protein digestibility-corrected amino acid score. Cienc. Technol. Aliment. Campinas, 31(1), 264-269.

Niang, I., Ruppel, O.C., Abdrabo, M.A., Essel, A., Lennard, C., Padgham, J. \& Urquhart, P., (2014). Africa. In: Climate change 2014: Impacts, adaptation, and vulnerability. Part B: Regional aspects. Contribution of working group II to the fifth assessment report of the intergovernmental panel on climate change [Barros, V.R., et al., (eds.)]. Cambridge University press, Cambridge, United Kingdom and New York, NY, USA, pp. 1199-1265.

Nkhata, S. G., Ortiz, D., Baributsa, D., Hamaker, B., Rocheford, T., \& Ferruzzi, M. G. (2019). Assessment of oxygen sequestration on effectiveness of Purdue improved crop storage (PICS) bags in reducing carotenoid degradation during post-harvest storage of two biofortified orange maize genotypes. Journal of Cereal Science, 87, 68-77.

Nuss, E. T., \& Tanumihardjo, S. A. (2010). Maize: A paramount staple crop in the context of global nutrition. Comprehensive Reviews in Food Science and Food Safety, 9, 417-436.

Oerke, E. C. (2006). Crop losses to pests. Journal of Agricultural Science, $144,31-43$

Omotayo, O.P., Omotayo, A.O., Mwanza, M., Babalola, O.O., 2019. Prevalence of mycotoxins and their consequences on human health. Toxicological Research, 35(1): 1-7.

Ortiz, D., Rocheford, T., \& Ferruzi, M. G. (2016). Influence of temperature and humidity on the stability of carotenoids in biofortified maize (Zea mays L.) genotypes during controlled post-harvest storage. Journal of Agricultural and Food Chemistry, 64, 2727-2736.

Pandey, V., \& Pandey, N. D. (1977). Changes in chemical constituents of various maize varieties due to infestation caused by Sitotroga cerealella Oliver. Bulletin Grain Technology, 15, 27-30.

Pingale, S. V., Narayana Rao, M., \& Swaminathan, M. (1954). Effect of insect infestation on stored grain. I. studies in soft wheat. Journal of the Science of Food and Agriculture, 5(1), 51-54.
Rajan, P., Daniel, V. A., Padmarani, R., \& Swiminathan, M. (1975). Effect of insect infestation on the protein efficiency ratio of proteins of maize and cowpea. Indian Journal of Nutrition and Dietetics, 12(11), 354-357.

Rajan, P., Sanjeevarayappa, K. V., Daniel, V. A., Jayaraj, A. P., \& Swaminathan, M. (1975a). Effect of insect infestation on the chemical composition and nutritive value of maize and cowpea. Indian Journal of Nutrition and Dietetics, 12(10), 325-332.

Ramirez, M. M., \& Silver, B. J. (1983). Deterioration and damage produced in corn grains in Mexico by Prostephanus truncatus (Horn) (Coleoptera: Bostrichidae). Biodeterioration, 5, 583-591.

Reed, C., Doyungan, S., Ioerger, B., \& Getchell, A. (2007). Response of storage moulds to different initial moisture contents of maize (corn) stored at $25 \mathrm{C}$ and effect on respiration rate and nutrient composition. Journal of Stored Products Research, 43, 443-458.

Rees, D., \& Hammond, L. (2002). Chapter 2. Biology of plant commodities. In (Golob, P., Farrell, G., orchard, J.E., (eds.)) crop postharvest science and technology, Vol 1: Principles and practices (pp. 35-68). UK: Blackwell Science Ltd..

Rembold, F., Hodges, R., Bernard, M., Knipschild, H., \& Leo, O. (2011). The African postharvest losses information system (APHLIS): An innovative framework to analyse and compute quantitative postharvest losses for cereals under different farming and environmental conditions in east and southern Africa. JRC scientific and technical reports, EU 24712 EN - 2011. 76 pp. https://core.ac.uk/download/pdf/38621127.pdf

Riwa, W.H., Stathers, T., Morris, M., Mosha, R., Makwiya, P. \& Mvumi, B., (2005). A case study of the effectiveness of diatomaceous earth in protecting farm stored grain in Mlali village, Dodoma region, Tanzania. $6 \mathrm{pp}$. Paper presented at the regional symposium for post harvest research forum in eastern, central and southern Africa, Ridar hotel, Uganda.

Savary, S., Ficke, A., Aubertot, J.-N., \& Hollierm, C. (2012). Crop losses due to diseases and their implications for global food production losses and food security. Food Security, 4, 519-537.

Savary, S., Bregaglio, S., Willocquet, L., Gustafon, D., Mason D'Croz, D., Sparks, A., Castilla, N., Djurle, A., Allinne, C., Sharma, M., Rossi, V., Amorim, L., Bergamin, A., Yuen, J., Esker, P., McRoberts, N., Avelino, J., Duveiller, E., Koo, J., \& Garrett, K. (2017). Crop health and its global impacts on the components of food security. Food Security, 9, 311-327.

Schmidhuber, J., \& Tubiello, F. N. (2007). Global food security under climate change. Proceedings of the National Academy of Sciences, 104(50), 19703-19708.

Sharifi, S. (1972). Oviposition site and egg plug staining as related to development of two species of Sitophilus in wheat kernels. Zeitschrift für Angewandte Entomologie, 71, 428-431.

Sharifi, S., \& Mills, R. B. (1971). Radiographic studies of Sitophilus zeamais Mots. in wheat kernels. Journal of Stored Product Research, 7, 195-206.

Sheahan, M., \& Barrett, C. B. (2017). Review: Food loss and waste in sub-Saharan Africa. Food Policy, 70, 1-12.

Shephard, G. S. (2008). Impact of mycotoxins on human health in developing countries. Food Additives and Contaminants, 25(2), 146-151.

Singh, S., Singh, H. D., \& Sikka, K. C. (1968). Distribution of nutrients in the anatomical parts of common Indian pulses. Cereal Chemistry, 45, 13-18.

Smith, L. W., Pratt, J. J., Nii, I., \& Umina, A. P. (1971). Baking and taste properties of bread made from hard wheat flour infested with species of Tribolium, Tenebrio, Trogoderma, and Oryzaephilus. Journal of Stored Products Research, 6(4), 307-316.

Stathers, T. E. \& Mvumi, B. M. (in press 2020). Chapter 31. Challenges and initiatives in reducing postharvest food losses and food waste: Sub-Saharan Africa. In: Preventing food losses and waste to achieve food security and sustainability (eds. Yahia, E., de Queretaro, A.). Burleigh Dodds Science Publishing. ISBN: 978-1-78676-302-0.

Stathers, T., Lamboll, R., \& Mvumi, B. M. (2013). Postharvest agriculture in changing climates: its importance to African smallholder farmers. Food Security, 5(3), 361-392. 
Stathers, T., Ognakossan, K.E., Priebe, J., Mvumi, B.M., \& Tran, B.M.D. (2018). Counting losses to cut losses: quantifying legume postharvest losses to help achieve food and nutrition security. In: C.S. Adler, G. Opit, B. Fürstenau, C. Müller-Blenkle, P. Kern, F.H. Arthur, C.G. Athanassiou, R. Bartosik, J. Campbell, M.O. Carvalho, W. Chayaprasert, P. Fields, Z. Li, D. Maier, M. Nayak, E. Nukenine, D. Obeng-Ofori, T. Phillips, J. Riudavets, J. Throne, M. Schöller, V. Stejskal, H. Talwana, B. Timlick, P. Trematerra (eds.) Proceedings of the $12^{\text {th }}$ International Working Conference on Stored Product Protection (IWCSPP), Berlin, Germany, October 7-11, 2018. Volume 1, 8-18. http://spiru.cgahr.ksu.edu/proj/iwcspp/iwcspp12.html

Steel, R. G. D., Torrie, J. H., \& Dickey, D. A. (1997). Principles and procedures of statistics a biometrical approach (3rd ed.666 pp). New York: McGraw-Hill.

Subramanyam, B., Cutkomp, L. K., \& Kouable, B. (1987). Effects of short-term feeding by adults of Prostephanus truncatus (Horn) (Coleoptera: Bostrichidae) on shelled maize. Journal of Stored Products Research, 23, 151-155.

Taleon, V., Mugode, L., Cabrera-Soto, L., \& Palacios-Rojas, N. (2017). Carotenoid retention in biofortified maize using different postharvest storage and packaging methods. Food Chemistry, 232, 60-66.

Tongjura, J. D. C., Amuga, G. A., \& Mafuyai, H. B. (2010). Laboratory assessment of the susceptibility of some varieties of Zea mays infested with Sitophilus zeamais, Motsch. (Coleoptera, Curculionidae) in Jos, plateau state, Nigeria. The Scientific World Journal, 5, 55-57.

United Nations Department of Economic and Social Affairs (UNDESA). (2017). World population prospects, 2017.

Venkat Rao, S., Nuggehalli, R.N., Swaminathan, M., Pingale, S.V., \& Subrahmanyam, V. (1958). Effect of insect infestation on stored grain. III. Studies on kaffir corn (Sorghum vulgare). Journal of the Science of Food and Agriculture, 8, 512.

Venkat Rao, S., Krishnamurthy, K., Narasimhan, K. S., Daniel, V. A., Majumder, S. K., \& Swaminathan, M. (1960). Assessment of insect infestation and acceptability of market samples of food grains. Part I. Studies on wheat flour. Food Science, 9(1), 8-10.

Vowotor, K. A., Meikle, W. G., Ayertey, J. N., Borgemeister, C., \& Markham, R. H. (1998). Intraspecific competition in larvae of the larger grain borer, Prostephanus truncatus (Horn) within maize grains. Insect Science and Its Application, 18, 171-175.

Weber, E. J. (1987). Carotenoids and tocols of corn grain determined by HPLC. Journal of the American Oil Chemists' Society, 64(8), 1129-1134.

Widstrom, N. W. (1979). The role of insects and other plant pests in aflatoxin contamination of corn, cotton, and peanuts - a review. Journal of Environmental Quality, 8, 5-11.

Wild, C. P., \& Gong, Y. Y. (2010). Mycotoxins and human disease: a largely ignored global health issue. Carcinogenesis, 31(1), 71-82.

World Bank, NRI, FAO. (2011). Missing Food: the case of postharvest grain losses in sub-Saharan Africa. The World Bank, US, report no: 60371-AFR. 116pp.

Wu, F., Narrod, C., Tiongco, M., Liu, Y. (2011). The health economics of aflatoxin: global burden of disease. IFPRI Aflacontrol working paper 4, Washington DC.

Zeleny, L. (1968). Nutritional evaluation of food processing. Harris, R.H., von Loescke, H., (Eds.) (p. 358). New York: Wiley and Sons.

Zhou, Z., Robards, K., Helliwell, S., \& Blanchard, C. (2002). Ageing of stored rice: Changes in chemical and physical attributes. Journal of Cereal Science, 35(1), 65-78.

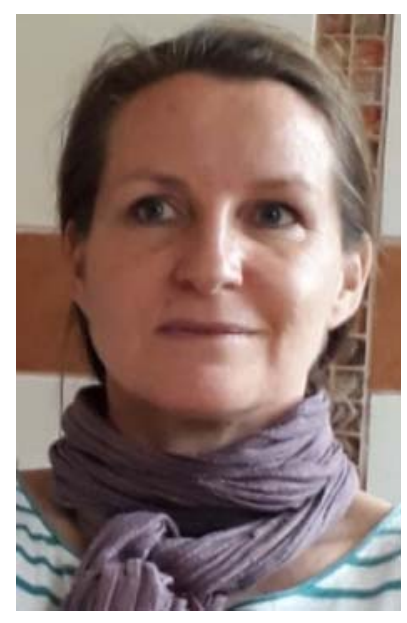

Dr Tanya Stathers has worked as an agriculture for development researcher across sub-Saharan Africa for $>25$ years, with a particular focus on: postharvest systems and the reduction and understanding of postharvest losses (including their nutritional and financial value) in staple grains and root and tuber crops; multi-stakeholder learning processes; agricultural adaptation to climatic and other changes; creative training materials and approaches; rural-urban interdependencies; gender and diversity aspects of agri-food systems; and poverty impacts of market standards. Her earlier work focused on: participatory development of pre and postharvest integrated pest management options for a range of smallholder produced cash and food crops; including diatomaceous earth grain protectants, entomopathogenic fungi, pheromones, natural enemies, resistant varieties and the farmer field school approach. She also supervises postgraduate research students and has developed and teaches on several training courses. She is an associate professor at the Natural Resources Institute (NRI) of the University of Greenwich.

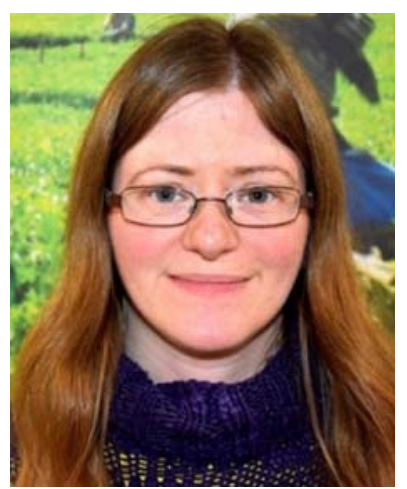

Dr Sarah Arnold is a behavioural entomologist with a background in host- and food-seeking behaviours of economically important insects. After completing a BA at the University of Cambridge in Natural Sciences (Plant Sciences), followed by $\mathrm{PhD}$ at Queen Mary, University of London, she has carried out research at the Natural Resources Institute on the behavioural ecology of postharvest pests including their responses to odour and colour stimuli, and participates in research projects exploring the application of pesticidal plants in pre- and postharvest pest management in smallholder farming systems in sub-Saharan Africa. 


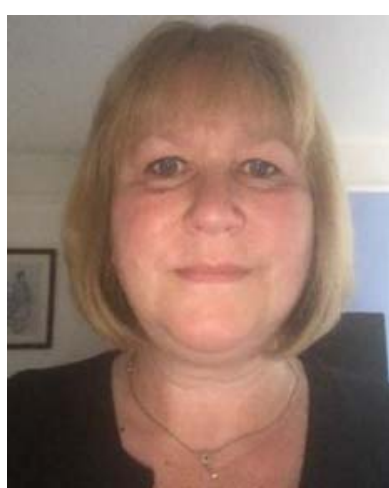

Dr Corinne Rumney graduated in Applied Biology, specialising in Nutrition and Toxicology and subsequently completed a $\mathrm{PhD}$ in the microbial biochemistry of human gut microflora. For almost ten years she worked at the interface between diet, gut microflora and potential genotoxicity in the colon. After a career break she joined the science department of a secondary school before taking on the role of research fellow / microbiologist / lab manager within the Food and Markets department of the NRI of the University of Greenwich. As well as ensuring the smooth running of the labs, she gets involved in a wide variety of food safety and quality and postharvest storage work, assists in practical classes for MSc programmes in Food Safety and Quality Management and Food Innovation and supervises masters students in their lab-based projects.

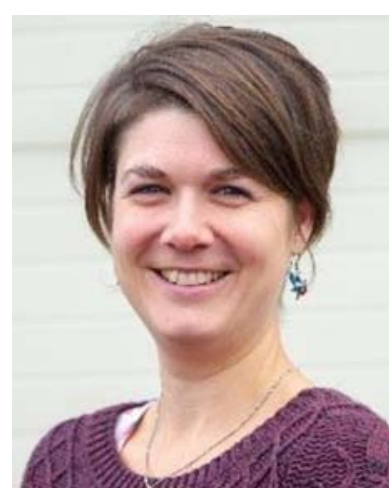

Clare Hopson has worked in science for over thirteen years within a range of disciplines, from plant breeding, entomology, and physiology to consumer research, profile testing and commercial farm. She has extensive experience of working on a variety of top and soft fruit, vegetables, ornamental plants and flowers. Clare is particularly interested in supporting commerce through research, turning theories into practicalities that will improve industry. She is a research assistant, based at the Produce Quality Centre part of the Natural Resources Institute (NRI) of the University of Greenwich. 